\title{
Estimation of Macromolecule Concentrations and Excluded Volume Effects for the Cytoplasm of Escherichia coli
}

\author{
Steven B. Zimmerman and Stefan O. Trach
}

\author{
Laboratory of Molecular Biology \\ National Institute of Diabetes and Digestive and Kidney Diseases \\ National Institutes of Health, Bethesda, MD 20892, U.S.A.
}

(Received 26 November 1990; accepted 24 June 1991)

\begin{abstract}
The very high concentration of macromolecules within cells can potentially have an overwhelming effect on the thermodynamic activity of cellular components because of excluded volume effects. To estimate the magnitudes of such effects, we have made an experimental study of the cytoplasm of Escherichia coli. Parameters from cells and cell extracts are used to calculate approximate activity coefficients for cytoplasmic conditions. These calculations require a representation of the sizes, concentrations and effective specific volumes of the macromolecules in the extracts. Macromolecule size representations are obtained either by applying a two-phase distribution assay to define a related homogeneous solution or by using the molecular mass distribution of macromolecules from gel filtration. Macromolecule concentrations in cytoplasm are obtained from analyses of cxtracts by applying a correction for the dilution that occurs during extraction. That factor is determined from experiments based upon the known impermeability of the cytoplasmic volume to sucrose in intact $E$. coli. Macromolecule concentrations in the cytoplasm of $E$. coli in either exponential or stationary growth phase are estimated to be $\approx 0.3$ to $0.4 \mathrm{~g} / \mathrm{ml}$. Macromolecule specific volumes are inferred from the composition of close-packed precipitates induced by polyethylene glycol.

Several well-characterized proteins which bind to $\mathrm{DN} \Lambda$ (lac repressor, $\mathrm{RN} \Lambda$ polymerase) are extremely sensitive to changes in salt concentration in studies in vitro, but are insensitive in studies in vivo. Application of the activity coefficients from the present work indicates that at least part of this discrepancy arises from the difference in excluded volumes in these studies. Applications of the activity coefficients to solubility or to association reactions are also discussed, as are changes associated with cell growth phase and osmotic or other effects. The use of solutions of purified macromolecules that emulate the crowding conditions inferred for cytoplasm is discussed.
\end{abstract}

Keywords: proteins; cytoplasm; excluded volume; macromolecular crowding; metabolic buffering

\section{Introduction}

Biological reactions occur naturally in the concentrated milieux of living cells (Kennell \& Riezman, 1977; Fulton, 1982; Woldringh \& Nanninga, 1985), yet they are generally characterized in dilute solutions. The high volume-occupancy within cells must cause significant changes in many parameters of these reactions (Minton, 1981, 1983, 1990). In formal terms, the parameters determined under dilute, relatively ideal conditions can be corrected for highly concentrated conditions by applying appropriate activity coefficients. The problem then is the evaluation of activity coefficients for macromolecules of interest under in vivo conditions of excluded volume. Although such values will necessarily be rough estimates, they may still be quite useful as first approximations in view of the large corrections anticipated for certain cell reactions.

Escherichia coli contains two functionally and physically separated membrane-bounded spaces, namely the cytoplasmic and the periplasmic compartments (Ingraham et al., 1983; Oliver, 1987; Stock et al., 1977). The periplasm is readily released by lysozyme treatment of the cells; the resulting sphcroplasts can be gently ruptured to yield soluble macromolecules characteristic of the cytoplasm. We use the properties of such extracts to infer conditions in the cytoplasm. Excluded volume properties of the extracts are derived from gel filtration and 
two-phase partition assays (Zimmerman \& Trach, 1990). These results are combined with measurements of the dilution of the cytoplasm that occurs during the extraction process in order to estimate activity coefficients under cellular conditions. These calculations are made over a range of values for the average effective specific volume for the cytoplasmic contents indicated by the measurements given in the Appendix.

\section{Materials and Methods}

(a) General

Materials and procedures are as described (Zimmerman \& Trach, 1988b, 1990) where not specified.

\section{(b) Materials}

Crystallized chicken egg white lysozyme (grade I) was purchased from Sigma, erystallized pancreatic DNase I from Millipore, and Blue Dextran 2000 from Pharmacia.

\section{(c) Methods}

\section{(i) Cell and spheroplast preparation}

Cultures of $E$.coli C600 were grown with shaking (275 revs/min, New Brunswick gyrotory shaker, model G-25D) in 21 flasks containing $0.7 \mathrm{l}$ of Luria-Bertani medium (Maniatis et al., 1982) at $37^{\circ} \mathrm{C}$. Exponential cells grew with a generation time of $\approx 30 \mathrm{~min}$ and were harvested at $A_{600}=1.5$. Stationary phase cells were taken from cultures that were shaken $12 \mathrm{~h}$ after exponential growth ceased; these cultures had a final value of $\mathrm{pH} 7 \cdot 2$, comparable to that of the unused medium $(\mathrm{pH} 7 \cdot 5)$. Cultures were chilled and harvested by centrifugation. Cells for alumina extraction were washed several times with cold $0.15 \mathrm{M}-\mathrm{NaCl}$ and the well-drained cell pellets were frozen with solid $\mathrm{CO}_{2}$ and stored at $-20^{\circ} \mathrm{C}$.

$\mathrm{Mg}^{2+}$-stabilized spheroplasts were prepared by the TFS lysozyme treatment described by Witholt et al. $(1976 a, b)$ using cells freshly grown as described above and washed in $1 \mathrm{~mm}-\mathrm{MgCl}_{2}, 200 \mathrm{~mm}$-Tris $\cdot \mathrm{HCl}(\mathrm{pH} 8 \cdot 0)$. Quantitative conversion of either exponential or stationary phase cells to spheroplasts was indicated by $>95 \%$ of the cells becoming spherical and by $>95 \%$ lysis of portions of the culture based on a direct count after a 12 -fold dilution in water. After addition of $\mathrm{MgCl}_{2}$ to stabilize the spheroplasts, cultures were chilled and spheroplasts collected by centrifugation; the supernatant fluids contained 8 to $11 \%$ of the total cell protein and 2 to $4 \%$ of the total cell RNA. The well-drained spheroplast preparations were frozen with solid $\mathrm{CO}_{2}$ and stored at $-20^{\circ} \mathrm{C}$.

Cell pellets of washed exponential or stationary phase cells contained 0.241 or $0.239 \mathrm{~g} \mathrm{dry}$ weight/g packed cells. similar to previous values (Roberts et al., 1955; Schultz \& Solomon, 1961; Winkler \& Wilson. 1966); dry weights of extracts are listed in the text

\section{(ii) Extraction of cells and spheroplasts}

Concentrated extracts of whole cells were made by grinding a partially thawed pellet of cells for $4 \mathrm{~min}$ in a chilled mortar at $5^{\circ} \mathrm{C}$ with $1.7 \mathrm{~g}$ alumina (type $\mathrm{A}-5$. Sigma)/g wet weight of cells. The sticky paste was triturated for several minutes with $0.95 \mathrm{ml} / \mathrm{g}$ wet weight of cells of extraction buffer $(17.4 \mathrm{~mm}$-Tris $\cdot \mathrm{HCl}$ (pH 7.5), $52 \cdot 1 \mathrm{mM}-\mathrm{NH}_{4} \mathrm{Cl}, \quad 17 \cdot 4 \mathrm{~mm}-\mathrm{MgCl}_{2}, \quad 10 \cdot 4 \mathrm{~mm}-\beta$-mercaptoethanol, $\mathrm{l} \cdot 7 \mu \mathrm{g}$ pancreatic DNase $\mathrm{I} / \mathrm{ml}$ )
Concentrated extracts of spheroplasts were prepared at 0 to $5^{\circ} \mathrm{C}$ by manually dispersing a thawed pellet of spheroplasts in $0.95 \mathrm{ml}$ of extraction buffer $/ \mathrm{g}$ wet weight of spheroplast pellet in a tube with a loosely fitting Teflon pestle.

Extracts were incubated for $20 \mathrm{~min}$ at $20^{\circ} \mathrm{C}$ to decrease their viscosity, chilled and centrifuged for $10 \mathrm{~min}$ at $39,000 \mathrm{~g} \quad(18,000 \mathrm{revs} / \mathrm{min}$ in a $\mathrm{SS}-34$ rotor. DuPont/Sorvall centrifuge, model $\mathrm{RC}-5$ at $\left.5^{\circ} \mathrm{C}\right)$. About $2 / 3$ of the supernatant fluids were removed by pipette. and either used directly (for extracts of whole cells) or recentrifuged as described above and the final supernatant fluid used (for extracts of spheroplasts). Portion of these "low-speed extracts" were further centrifuged for $6 \mathrm{~h}$ at $106,000 \mathrm{~g}(30,000 \mathrm{revs} / \mathrm{min}$ in a Beckman/Spinco type 30 rotor at $5^{\circ} \mathrm{C}$ ) to remove ribosomes (Traub et al. 1971); the resulting supernatant fluids are termed "highspeed extracts". Extracts were frozen in portions in solid $\mathrm{CO}_{2}$ and stored at $-20^{\circ} \mathrm{C}$

The above protocols are designed to vield extracts containing the nominal concentrations of the component of solution I (Traub et al., 1971), namely $10 \mathrm{~mm}$-Tris. HCl $(\mathrm{pH} 75), 30 \mathrm{mM}-\mathrm{NH}_{4} \mathrm{Cl}, 10 \mathrm{~mm}-\mathrm{MgCl}_{2}, 6 \mathrm{~mm}-\beta$-mercaptoethanol, as well as $1 \mu \mathrm{g}$ pancreatic DNase $\mathrm{I} / \mathrm{ml}$. based upon an initial assumption of $\approx 0.70 \mathrm{~g}$ water/g wet weight of cells or spheroplasts (Neidhardt, 1987).

\section{(iii) Water content, dry weight and density measurements}

Water content and dry weights were generally based upon weight loss on drying of samples that were lyophilized and then dried at $104^{\circ} \mathrm{C}$ in vacuo until constant weight (see Appendix also). Sample densities were measured by weighing portions of 300 to $500 \mu \mathrm{l}$ contained in tared plastic tips of a pipetting device (model P-1600, Rainin Instrument (o.).

\section{(iv) Hard sphere representation of macromolecules and effective specific volume}

Macromolecules are represented as equivalent hard spheres in excluded volume interactions (Minton. 1983). The effective specific volume for the hard sphere model in excluded volume interactions is the specific volume of the equivalent hard sphere, $v(\mathrm{ml} / \mathrm{g})$, where

$$
v_{i} \equiv \frac{4 \pi R_{i}^{3} N_{\text {Avogadro }}}{3 M_{i}}
$$

and $R_{i}$ is the hard-sphere radius of a particle of molecular mass $M_{i}$. An experimental approach to $v$ is deseribed in the Appendix.

\section{(v) Concentrution of macromolecules in cell extrtats relative} to their concentration in $\mathrm{F}$. coli cytoplasm

To estimate the concentration of cytoplasmic macro molecules based on the concentrations of extract macro molecules, the latter must be quantified and the dilution associated with extraction must be determined.

The soluble macromolecules in E.coli are mostly composed of RNA and protein (Neidhardt, 1987). In our soluble, DNA-depleted extracts. both the weight of acidprecipitable macromolecules and the total dry weight of solutes are within $10 \%$ of the total weight of (RNA + protein) (see Table 1). We take the total (RNA + protein) content of a cell fraction as an operational definition of its macromolecule content.

The dilution upon extraction is measured by 2 methods. both of which use exclusion of sucrose from the cytoplasmic compartment of intact E. coli to operationally define the (ytoplasmic volume (Stock et al. 1977). 
Method I. This procedure is adapted from the thick suspension technique described by Mitchell \& Moyle (1956) and Weibull (1956). Portions of a very concentrated suspension of $E$. coli $(0 \cdot 5 \mathrm{ml}$ of $70 \%$ (w/w) suspension of cells that were grown as described above and washed in $0.154 \mathrm{M}-\mathrm{NaCl}$ ) were equilibrated for $30 \mathrm{~min}$ at $0^{\circ} \mathrm{C}$ with $12 \mu \mathrm{mol}$ sucrose in a total volume of $0.6 \mathrm{ml}$ in a tared tube; after centrifugation for $10 \mathrm{~min}$ at $10,000 \mathrm{~g}$ at $5^{\circ} \mathrm{C}$, the sucrose concentration of the supernatant fluid was determined. The total weight of water in each reaction mixture, $u_{\text {total }}$, and the water contents of the supernatant fluids were determined by drying.

The total weight of water is the sum of contributions from the periplasmic, cytoplasmic and intercellular volumes of the cell pellet and from the extraction buffer:

$$
w_{\text {total }}=w_{\text {periplasm }}+w_{\text {cytoplasm }}+w_{\text {intercellular }}+w_{\text {buffer }} \text {, }
$$

where $w$ is the weight of water. By definition, the wcight of water in the sucrose-permeable fraction of the reaction mixture is:

$$
w_{\text {permeable }}=w_{\text {periplasm }}+w_{\text {intercellular }}+w_{\text {buffer }} .
$$

The cytoplasmic water content for the cells added to the reaction mixture is given by:

$$
w_{\text {cytoplasm }}=w_{\text {total }}-w_{\text {permeable }}
$$

$w_{\text {permeable }}$ is obtained by material balance for sucrose:

$$
w_{\text {permeable }}=\frac{m_{\text {no cells }} \cdot w_{\text {nocells }}}{m_{\text {cells }}},
$$

where $m_{\text {no cells }}$ and $m_{\text {cells }}$ are amounts of sucrose/unit weight of total water in the supernatant fluids from reaction mixtures lacking cells and in complete mixtures containing cells, respectively. $w_{\text {total }}$ is determined as described above, so that $w_{\text {cytoplasm }}$ may be obtained from eqn (4).

The ratio of $w_{\text {total }} / w_{\text {cytoplasm }}$ gives the dilution of the extract on the basis of water content. Correction of the (RNA + protein) concentrations of the spheroplast extracts in Table 1 (using concentrations expressed on the basis of water content for this purpose) for this dilution gives the cytoplasmic concentration of (RNA + protein) in wcight/weight of cytoplasmic water. This cytoplasmic concentration may be converted to the concentration of (RNA + protein) on a weight/volume basis, $C_{\text {cytoplasm, by }}$ using the observed specific volume of solutes in spheroplast extracts $(0.66$ to $0.67 \mathrm{ml} / \mathrm{g}$ based upon dry weight and density determinations).

Method $1 I$. In this method, developed for the present study, cells were both washed and extracted in media containing the same concentration of sucrose; the sucrose concentration in the extract is lowered by release of the sucrose-free, cytoplasmic volume during extraction. Specifically, cells were washed with either $0 \cdot 139 \mathrm{~m}-\mathrm{NaCl}$ in $0.031 \mathrm{M}$-sucrose or $0.077 \mathrm{M}-\mathrm{NaCl}$ in $0.154 \mathrm{M}$-sucrose or $0.31 \mathrm{~m}$-sucrose, all of which are of approximately equal osmolality to our usual $0 \cdot 154 \mathrm{M}-\mathrm{NaCl}$ wash medium. The washed cells were extracted with alumina as described above, except that the extraction medium contained the same concentration of sucrose used in washing the cells. After centrifugation as described above for preparation of low-speed extracts, the sucrose concentration was measured in the cell extract.

Assuming additivity of the volumes involved, extract solution volume is given by:

$$
V_{\text {extract }}=V_{\text {buffer }}+V_{\text {intercellular }}+V_{\text {cyloplasm }}+V_{\text {periplasm }}
$$

where $V$ is the solution volume. Since $V_{\text {cytoplasm }}$ does not equilibrate with sucrose before cell breakage, the fraction of $V_{\text {extract }}$ that equilibrates with the sucrose concentration $\left(S_{0}\right)$ of the cell wash and extraction media is:

$$
\left(V_{\text {extract }}-V_{\text {cytoplasm }}\right)
$$

the part of $V_{\text {extract }}$ that equilibrates with the sucrose concentration $(S)$ in the extract is:

$$
\left(V_{\text {buffer }}+V_{\text {intercellular }}+k \cdot V_{\text {cytoplasm }}+V_{\text {periplasm }}\right),
$$

(where $k$ is the fraction of cells broken by the alumina treatment; $k \approx 0.95$ based upon comparison of alumina extract and spheroplast lysate compositions) which, by eqn $(6)$ is equivalent to:

$$
\left(V_{\text {extract }}-(1-k) V_{\text {cytoplasm }}\right) \text {. }
$$

Since the total amount of sucrose added to the extraction mixture is equal to the total amount of sucrose present after the alumina grinding (see control below), then

$$
\left(V_{\text {extract }}-V_{\text {cytoplasm }}\right) S_{0}=\left(V_{\text {extract }}-(1-k) \cdot V_{\text {cytoplasm }}\right) S \text {. (7) }
$$

Rearranging

$$
V_{\text {cyloplasm }}=\frac{1-S / S_{0}}{V_{\text {extract }}}=\frac{1-(1-k)\left(S / S_{0}\right)}{1-}
$$

The ratio of cytoplasmic volume to extract volume obtained in eqn (8) is used to convert the observed total concentration of (RNA + protein) for that extract, $C_{\text {extract }}$, to that in the cytoplasm, $C_{\text {cytoplasm }}$

$$
C_{\text {cytoplasm }}=\frac{C_{\text {extract }} \cdot V_{\text {extract }}}{V_{\text {cytoplasm }}}
$$

Control "extractions" in which cells were replaced by an equivalent amount of extraction medium (containing either 0.031 or $0.31 \mathrm{~m}$-sucrose) caused $<5 \%$ difference between the sucrose concentrations in the input medium and in the respective "extracts", indicating no significant differential adsorption of sucrose by the alumina.

Method II has the advantages of correcting extract concentrations back to the cytoplasmic compartment of the whole cell, and is on a solution basis rather than in terms of water content. Combining $C_{\text {cytoplasm }}$ values with assay results for spheroplast extracts requires that the same materials are extracted in alumina extracts of whole cells and in spheroplast extracts; gel and other analyses in Results support this assumption.

The $C_{\text {cytoplasm }}$ values obtained by either of the above methods are converted to values for the volume fraction effectively occupied by the cytoplasmic (RNA + protein), $\Phi$, by applying values for the effective specific volume for excluded volume interactions, $v$

$$
\Phi=v \cdot C_{\text {cytoplasm }} \text {. }
$$

(vi) Partition assay and the use of equivalent homogeneous solutions to represent mixtures of macromolecules

We have described an assay for volumes of macro molecules or average volumes of mixtures of macromolecules in excluded volume interactions based upon distribution coefficients of the macromolecules in an aqueous 2-phase system containing PEG $8000 \dagger$ and potassium phosphate (Zimmerman \& Trach, 1990) Distribution coefficients of a series of proteins and other materials in this system are largely determined by their excluded volume interactions with PEG 8000; current studies indicate a similar basis for distribution of a series of DNA oligonucleotides (our unpublished results).

† Abbreviation used: $\mathrm{PEG}$, polyethylene glycol 


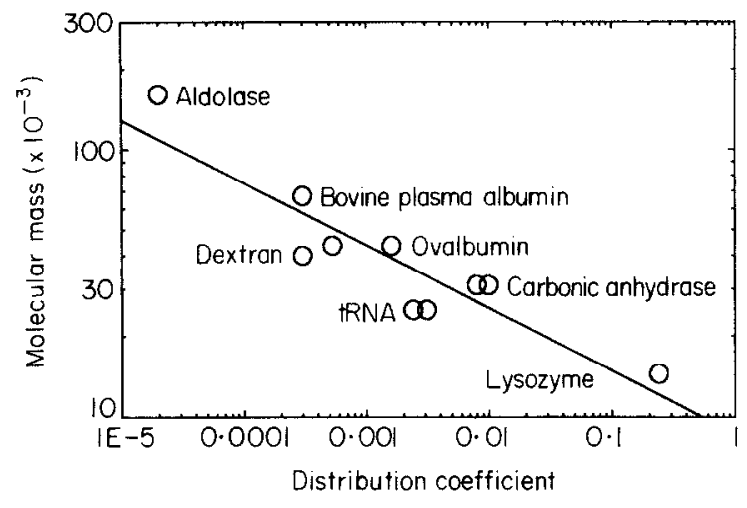

Figure 1. Two-phase partition assay calibration. The line is the first-order regression fit to the points.

Tie-line A (op. cit.) is used in the current experiments: sampling of the phases is as before with additional analyses where indicated. The partition assay was standardized in terms of the distribution coefficients of a series of purified proteins (Fig. 1), assuming the molecular masses listed by Chrambach (1985).

The distribution coefficient of a cell extract in terms of its total RNA and protein yields an average molecular mass for those components of the extract by application of Fig. 1. This molecular mass is converted using eqn (1) to the radius $R^{*}$ for the solute of a related homogeneous hard-sphere solutiont. Values of $R^{*}$ are weighted by the relative covolumes of the extract components with PEG 8000 . This weighting is corrected by eqn (A8) of Zimmerman \& Trach (1990), using the size distribution of the extract in the form of its hard-sphere representation from gel filtration. The correction of $R^{*}$ yields the radius $\left(R_{\mathrm{e}}\right)$ of an effective hard sphere in a homogeneous solution that can be used to represent the extract in calculating approximate activity coefficients for component particles. The use of equivalent homogeneous solutions for this purpose is considered in the Appendix to Zimmerman \& Trach (1990). The corresponding particle concentration for this solution $\left(d_{\mathrm{e}}\right.$, particles $\left./ \mathrm{cm}^{3}\right)$ is obtained by dividing $\Phi$ by the spherical volume corresponding to $R_{\mathrm{e}}$

\section{(vii) Gel filtration}

The Sephacryl S-300 column was described (Zimmerman \& Trach, 1990). The elution medium (13.8\% $(\mathrm{w} / \mathrm{w})(1.05 \mathrm{M})$ potassium phosphate buffer $(\mathrm{pH} 7.0)$, in solution I) contains the average buffer concentration in the bottom phase of the partition assay. The column was standardized in terms of the relative elution volumes of a series of purified proteins (Fig. 2), assuming the molecular masses listed by Chrambach (1985).

Elution profiles were represented as hard sphere distributions as follows. The average molecular mass for each fraction in the gel filtration pattern was based upon the calibration of Fig. 2. Cumulative plots of (RNA + protein) versus molecular mass were used to determine the amounts of (RNA + protein) in each of the molecular mass ranges shown in Fig. 5. The amounts of RNA in material of $M_{\mathrm{r}}>200,000$ was represented in equimolar amounts of ribosomal fractions of $M_{\mathrm{r}}=900,000$ and

† The distribution assay can also be used to estimate an effective radius of hard-sphere equivalent particles for an individual component of a cell extract from its distribution coefficient using Fig. I and eqn (1).

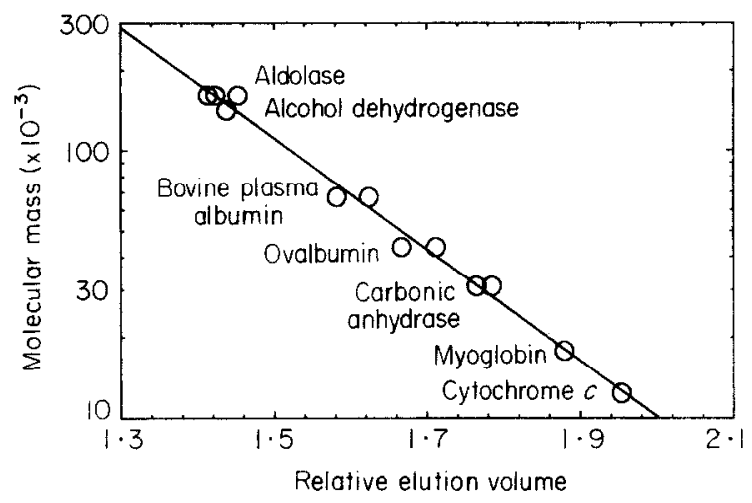

Figure 2. Sepharryl $\$-300$ column calibration. 'The relative elution volume is the ratio of the peak elution volume for a given material to the peak elution volume for Blue Dextran 2000. The line is the first-order regression fit to the points.

$1,550,000 ;$ the results of this study are very insensitive to the sizes assumed for this large material. The average molecular masses for the molecular mass ranges were converted to radii of equivalent hard spheres for various values of effective specific volume by eqn (1); these radii were then used to compute $\gamma$ values with eqn (II).

For certain computations, the hard sphere distributions based upon gel filtration profiles describer in the preceding paragraph were replaced by homogeneous hard sphere populations that emulate certain excluded volume properties of the whole distributions. Parameters (radius $R_{\mathrm{a}}$, particle concentration $d_{\mathrm{a}}$ ) for these homogeneous populations were calculated from the hard sphere distributions with eqns (A1) and (A2) of Zimmerman \& Trach (1990). The distributions given in the preceding paragraph were also used to calculate theoretical values for an experimental parameter from the 2-phase assay, $R^{*}$ (see subsection (vi), above) by subtracting $\left(R_{\mathrm{a}}-R^{*}\right)$ (calculated by means of eqn (A8) of Zimmerman \& Trach (1990) for the PEG 8000 concentrations measured in the determination of $R^{*}$ in the 2-phase assay) from $R_{\mathrm{a}}$.

\section{(viii) Polyacrylamide gel electrophoresis}

Trichloroacetic acid-precipitated samples for gel electrophoresis were redissolved in the final sample buffer describer by Laemmli (1970), incubated for $2 \mathrm{~h}$ at $37^{\circ} \mathrm{C}$ (Sigma Technical Bulletin, 1982), and applied to SDS/polyacrylamide gels slightly modified from those of Laemmli $(1970)$ to contain a $5 \%(\mathrm{w} / \mathrm{v})$ stacking gel and $12 \%(\mathrm{w} / \mathrm{v})$ separation gel with a ratio of acrylamide to bis-acrylamide of 20 ; gels were rinsed with $10 \%(\mathrm{w} / \mathrm{v})$ trichloroacetic acid $33 \%(\mathrm{v} / \mathrm{v})$ methanol and stained with Coomassie brilliant blue G-250 (Blakesley \& Boezi, 1977). Gel patterns were quantificd with a scanning densito meter (Hoefer model GS-300 with a (KS-360 data system). Variations in lane width for samples containing high amounts of PEG 8000 were minimized by surrounding

$\$$ Calculations with eqns (A2) and (A8) of Zimmerman \& Trach (1990) require a value for the averaged effective radius of $\mathrm{PEG} 8000$ for the partition system. $R_{\text {PEG 8000 }}$. Values of $R_{\text {PEG } 8000}$ of 1.70 or $1.47 \mathrm{~nm}$ were calculated as described there for $v=1.0$ or $1.3 \mathrm{ml} / \mathrm{g}$. respectively, from the PEG 8000 entries in Table 1 of that reference. 
those lanes with lanes loaded with the same amounts of PEG 8000

\section{(ix) Colorimetric determinations}

RNA content was determined from the amount of purine-bound ribose that reacted with orcinol (Ashwell, 1957), using a factor of $0.65 \mu \mathrm{g} \mathrm{RNA} / \mathrm{nmol}$ reactive ribose. This conversion factor assumes the average base composition for $E$. coli RNA in Table 2 of Lombard \& Chargaff (1957). Variation in the relative amounts of ribosomal and tRNA should not significantly affect this calibration given the relatively small amounts of tRNA (Neidhardt, 1987) and its general similarity in purine content to that of rRNA (purine/pyrimidine $\approx 1.0$ for tRNA and $\approx 1.3$ for rRNA: Sirlin, 1972). Our calibration agrees within $10 \%$ of that of Forschhammer \& Lindahl (1971).

Protein was estimated by the method of Lowry et al. (1951) and by the biuret procedure (Gornall et al., 1949). Crystallized bovine plasma albumin was used as a standard after correcting for the water lost $(4 \cdot 2 \%)$ upon drying under vacuum at $104^{\circ} \mathrm{C}$. For the 2 -phase distribution and gel filtration samples, the more sensitive procedure of Lowry et al. (1951) was applied to portions precipitated with $5 \%(\mathrm{w} / \mathrm{v})$ trichloroacetic acid and collected by centrifugation; precipitation caused $<5 \%$ difference in apparent protein content when tested with a number of extract samples. Protein concentrations of extracts that were used in determining cytoplasmic protein concentrations were estimated with the much less sensitive but more uniformly responsive biuret procedure. The average deviation between apparent protein concentrations of representative extracts when measured in the procedure of Lowry et al. (1951) versus that of Gornall et al. (1949) was $4 \%$.

Sucrose was determined by the resorcinol reaction (regular assay: Monsigny et al., 1988) in the fraction of samples that was soluble in cold $5 \%$ trichloroacetic acid.

(x) Calculation of activity coefficients by scaled particle theory

An activity coefficient $\left(\gamma_{i}\right)$ is calculated for an infinitely dilute solution of a spherical "test particle" as a function of its radius $\left(R_{i}\right)$ when the test particle is present in various "backgrounds" of spherical particles. Calculations were made using the scaled particle theory (Reiss, 1965), with an equation for spherical particles (eqn (A3) and sphere parameters from Table A1 of Chatelier \& Minton (1987)). For the $i$ th test particle:

$$
\begin{aligned}
\ln \gamma_{i}=-\ln (1-\Phi)+\frac{B R_{i}}{1-\Phi}+\frac{4 \pi A R_{i}^{2}}{1-\Phi}+\frac{B^{2} R_{i}^{2}}{2(1-\Phi)^{2}} \\
+\frac{4 \pi}{3}\left[\frac{d}{1-\Phi}+\frac{B^{2} \mathrm{C}}{3(1-\Phi)^{3}}+\frac{A B}{(1-\Phi)^{2}}\right] R_{i}^{3},
\end{aligned}
$$

where $\Phi$, the volume fraction effectively occupied by cytoplasmic macromolecules, is evaluated as in section (v), above.

For calculation of $\gamma_{i}$ values based upon partition assay results, the background is the homogeneous solution of spheres of radius $R_{\mathrm{e}}$ and number density, $d_{\mathrm{e}}$. In this case, the parameters for eqn (11) are $d=d_{\mathrm{e}}=3 \Phi /\left(4 \pi R_{\mathrm{e}}^{3}\right), A=$ $d R_{\mathrm{e}}, B=4 \pi d R_{\mathrm{e}}^{2}$, and $C=d R_{\mathrm{e}}^{2}$

For calculation of $\gamma_{i}$ values based upon molecular mass distributions from gel filtration patterns, the parameters for eqn (11) are $d=\Sigma_{j} d_{j}, A=\Sigma_{j} d_{j} R_{j}, B=\Sigma_{j} 4 \pi d_{j} R_{j}^{2}$, and $C=\Sigma_{j} d_{j} R_{j}^{2}$, where $d_{j}$ and $R_{j}$ are the number density and radius, respectively, of the hard sphere representations of the $j$ th molecular mass fraction in the gel filtration profile.

\section{Results}

\section{(a) Approaches and terminology}

We seek representations of cell extracts that can be used as cytoplasm-like backgrounds for calculations of activity coefficients of test particles. One approach is to determine the molecular size distribution of the extracts by gel filtration, and to represent this distribution as an equivalent distribution of hard spheres (Fig. 3). This hard sphere distribution can be used for scaled particle calculations of the desired activity coefficient $(\gamma)$ values. An entire distribution can also be conceptually replaced for scaled particle calculations by a homogeneous hard sphere solution (radius $R_{\mathrm{a}}$, particle concentration $d_{\mathrm{a}}$ ). Such a homogeneous substrate solution serves to suggest solutions of purified macromolecules for use as experimental background solutions for studies of crowding in cytoplasm (see Discussion).

A second assay technique, two-phase partition, is also used on extracts to obtain parameters of related homogeneous hard sphere solutions (Fig. 3). The two-phase assay gives the radius of a hard sphere, $R^{*}$ (Materials and Methods, section (c) (vi)), which can be compared with its theoretical value calculated for the molecular size distributions determined by gel filtration (Materials and Methods, section (c) (vii)). The $R^{*}$ values from the partition assay must be corrected (for their co-volume weighting with the PEG 8000 of the phase system) with information from the gel filtration system to obtain parameters of a homogeneous solution of hard spheres (characterized by $R_{\mathrm{e}}, d_{\mathrm{e}}$ ) (Materials and Methods, section (c) (vi)), which can be used in scaled particle calculations of $\gamma$ values. Because of this correction, the two-phase assay data are not an independent source of $\gamma$ values, but rather provide an alternative route to calculation of the desired activity coefficients which incorporates additional extract parameters. The agreement between the results from these two routes helps to test some of the assumptions of the approach as well as the calibrations of the assays.

The various radii that are used to characterize the background solutions should be distinguished from the radius $\left(R_{i}\right)$ of the test particle; it is the changes in activity coefficients of the test particles caused by the crowding effects of the background population that are being computed.

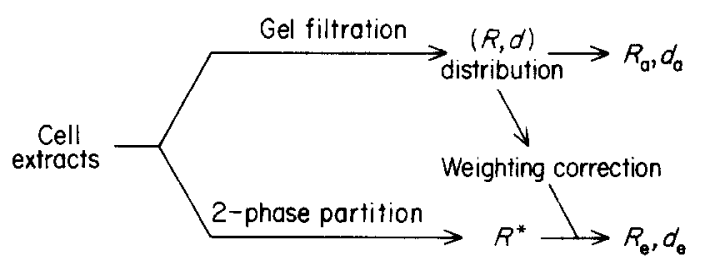

Figure 3. Hard sphere parameters used in representing the extracts. $R$, radius; $d$, concentration. $\left(R_{\mathrm{a}}, d_{\mathrm{a}}\right)$ and $\left(R_{\mathrm{e}}, d_{\mathrm{e}}\right)$ deseribe homogeneous solutions that ean be used to calculate activity coefficients, as can the observed size distribution $(R, d)$ 
Table 1

Composition of extracts

\begin{tabular}{|c|c|c|c|c|}
\hline $\begin{array}{l}\text { Source of } \\
\text { extract }\end{array}$ & $\begin{array}{l}\text { Protein } \\
(\mathrm{mg} / \mathrm{ml})\end{array}$ & $\begin{array}{c}\text { RNA } \\
(\mathrm{mg} / \mathrm{ml})\end{array}$ & $\begin{array}{l}\text { RNA+ } \\
\text { protein } \\
(\mathrm{mg} / \mathrm{ml})\end{array}$ & $\begin{array}{l}\text { Dry weight } \\
(\mathrm{mg} / \mathrm{ml})\end{array}$ \\
\hline \multicolumn{5}{|c|}{ A. Exponential phase cells } \\
\hline Spheroplasts & $69 \cdot 5$ & $25 \cdot 9$ & $95 \cdot 4$ & $88.0 \dagger$ \\
\hline Whole cells & $\begin{array}{c}63 \cdot 3 \pm 1 \cdot 7 \ddagger \\
(40 \cdot 4 \|)\end{array}$ & $\begin{array}{c}26 \cdot 5 \pm 4 \cdot 1 \ddagger \\
(3 \cdot 0 \|)\end{array}$ & $\begin{array}{c}89 \cdot 8 \pm 4 \cdot 1 \ddagger \\
(43 \cdot 4 \| 1)\end{array}$ & $92 \cdot 8 \pm 1 \cdot 8 \S$ \\
\hline \multicolumn{5}{|c|}{ B. Stationary phase cells } \\
\hline Spheroplasts & $92 \cdot 2$ & $13 \cdot 9$ & $106 \cdot 1$ & $101 \cdot 0 \dagger$ \\
\hline Whole cells & $\begin{array}{c}57 \cdot 6,64 \cdot 0 \\
(53 \cdot 3 \|)\end{array}$ & $\begin{array}{c}19 \cdot 8,16 \cdot 9 \\
(1 \cdot 9 \|)\end{array}$ & $\begin{array}{c}77 \cdot 4,80 \cdot 9 \\
(55 \cdot 2 \|)\end{array}$ & \\
\hline
\end{tabular}

$\dagger$ Precipitated with $5 \%$ trichloroacetic acid; pellet collected by centrifugation and washed with absolute ethanol before drying.

$\ddagger$ Mean and standard deviation for 4 extracts.

$\S$ Mean and standard deviation for 3 extracts.

|| Supernatant fluid after high-speed centrifugation (high-speed extract, see Materials and Methods).

We evaluate two other parameters required for describing the background solutions, the concentration of macromolecules in the cytoplasmic compartment, $C_{\text {cytoplasm }}$ (Materials and Methods, section (c) (v)), and their average effective specific volume, $v$, in excluded volume interactions (Appendix). We test the effects of a range of $v$-values on the final activity coefficients.

\section{(b) Preparation and properties of extracts of $\mathrm{E}$. coli}

Extracts of $E$. coli were made both from spheroplasts and from whole cells. The spheroplast extracts, prepared by extraction into low osmolality media after freezing and thawing the spheroplasts, are used as a source of cytoplasmic components essentially free of periplasmic and outer envelope constituents. Whole cell extracts, prepared by grinding with alumina, are used to estimate in vivo concentrations of macromolecules and in tests for internal consistency of the data. The excluded volume contribution from ribosomes is assessed by comparing extracts before and after removal of ribosomes by centrifugation and by comparing extracts from cells in the exponential phase of growth with those from cells in stationary phase, since ribosome content decreases several-fold upon cessation of active growth (Mendelsohn \& Tissières, 1959).

RNA and protein contents of the extracts

Table 2

Comparison of compositions of cell extracts and phase fractions

\begin{tabular}{|c|c|c|c|c|}
\hline Extract & Fraction & $\begin{array}{l}\text { Volume } \\
\text { (ml) }\end{array}$ & $\begin{array}{l}\text { Protein } \\
\text { (mg) }\end{array}$ & $\begin{array}{l}\mathrm{RNA} \\
(\mathrm{mg})\end{array}$ \\
\hline \multicolumn{5}{|c|}{ A. Exponential phase cells } \\
\hline \multirow{6}{*}{$\begin{array}{l}\text { Low-speed } \\
\text { extract from } \\
\text { cells }\end{array}$} & Extract & $1 \cdot 0.5 \ddagger$ & $65 \cdot 2$ & $32 \cdot 2$ \\
\hline & Phase system: $†$ & & & \\
\hline & Top phase & $1 \cdot 36$ & $2 \cdot 3$ & $0 \cdot 18$ \\
\hline & Interphase & $<0 \cdot 05$ & $<2 \cdot 9$ & $<0 \cdot 79$ \\
\hline & Bottom phase & 0.54 & $67 \cdot 9$ & $33 \cdot 2$ \\
\hline & Pellet & $<0.03$ & $<2 \cdot 2$ & $<0.8$ \\
\hline \multirow{4}{*}{$\begin{array}{l}\text { Low-speed } \\
\text { extract from } \\
\text { spheroplasts }\end{array}$} & Extract & $1 \cdot 06 \div$ & $73 \cdot 7$ & $27 \cdot 5$ \\
\hline & Phase system: $\dagger$ & & & \\
\hline & Top phase & $1 \cdot 27$ & $2 \cdot 5$ & $0 \cdot 19$ \\
\hline & Bottom phase & 0.56 & $86 \cdot 3$ & $36 \cdot 0$ \\
\hline \multirow{4}{*}{$\begin{array}{l}\text { High-speed } \\
\text { extract from } \\
\text { cells }\end{array}$} & Extract & $1.05 \ddagger$ & $42 \cdot 5$ & $3 \cdot 18$ \\
\hline & Phase system:1 & & & \\
\hline & Top phase & $1 \cdot 36$ & $2 \cdot 3$ & 0.05 \\
\hline & Bottom phase & $0 \cdot 42$ & $40 \cdot 0$ & $3 \cdot 08$ \\
\hline \multicolumn{5}{|c|}{ B. Stationary phase cells } \\
\hline \multirow{4}{*}{$\begin{array}{l}\text { Low-speed } \\
\text { extract from } \\
\text { spheroplasts }\end{array}$} & Extract & $1 \cdot 06_{+}^{+}$ & $97 \cdot 8$ & 14.7 \\
\hline & Phase system: $\dagger$ & & & \\
\hline & Top phase & $1 \cdot 31$ & 50 & $0 \cdot 41$ \\
\hline & Bottom phase & 0.61 & $113 \cdot 9$ & $20 \cdot 0$ \\
\hline
\end{tabular}

† Composition of 2 -phase mixture containing the maximal amount of extract tested.

$\ddagger$ Volume of extract added to the 2-phase system. 


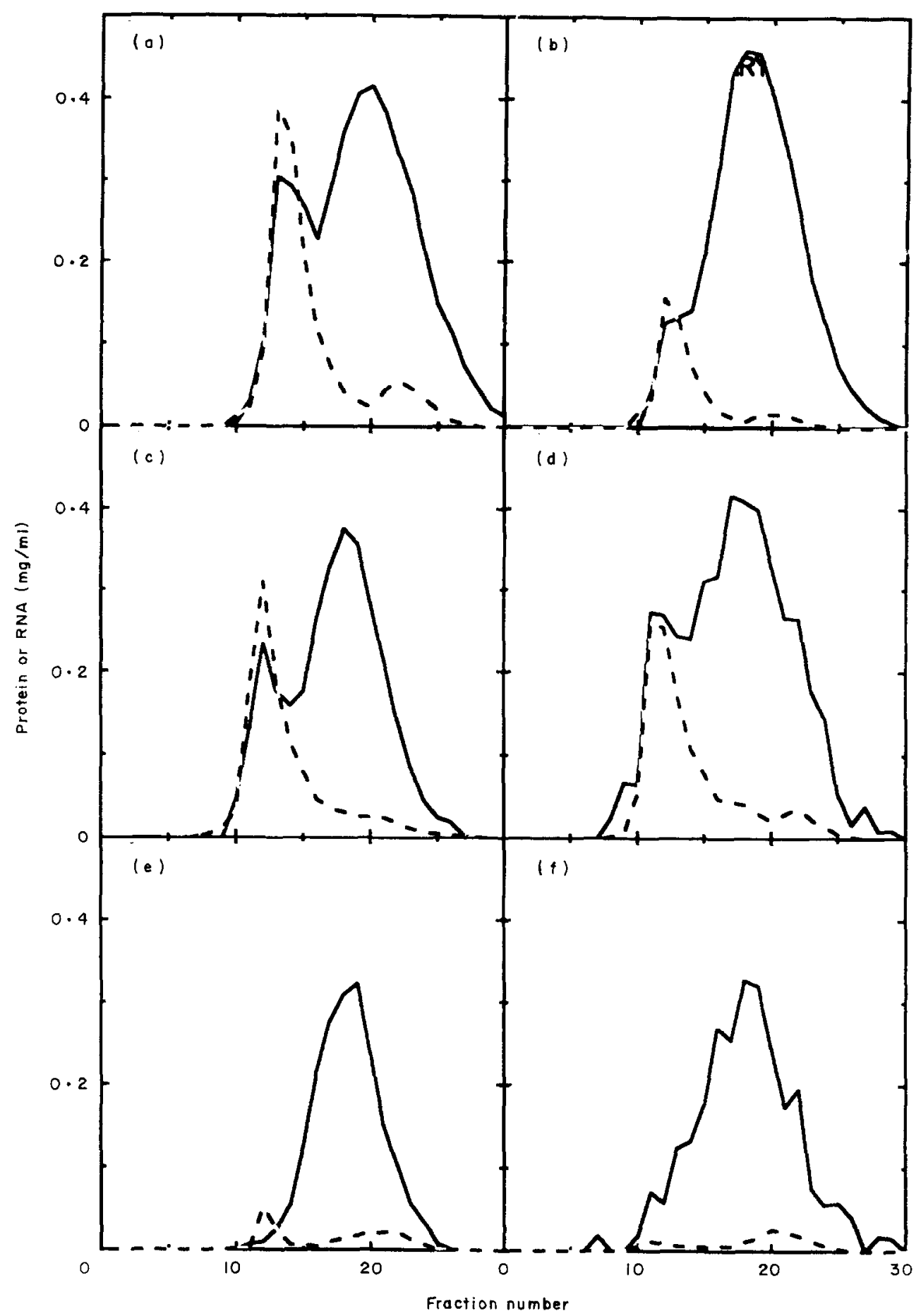

Figure 4. Gel filtration patterns of extracts and bottom phase samples. Portions containing $3 \cdot 0,3 \cdot 0,3 \cdot 0,3 \cdot 1,2 \cdot 0$ and $2.0 \mathrm{mg}$ protein, for (a) to (f), respectively, were applied to a Sephacryl S-300 column as described in Materials and Methods. For (c) and (e) these represented an equal volume of the low and high-speed extracts. Fractions of 0.70 to $0.84 \mathrm{ml}$ were collected in graduated tubes. (a) Extract of spheroplasts from exponential cells; (b) extract of spheroplasts from stationary cells; (c) extract of exponential cells; (d) bottom phase after partition of extract for (c): (e) high-speed extract of exponential cells; (f) bottom phase after partition of extract for (e). (- - ) Protein; (- - ) RNA.

described above are listed in Tables 1 and 2 and their gel filtration patterns are shown in Figure 4. The large amounts of ribosomes in extracts from exponential phase cells is reflected in their high RNA content and by ratios of RNA to protein in the fractions excluded from the gel matrix that are typical of ribosomes (Tissières et al., 1959; Fig. 4(a) and (c)). Diminished ribosomal contents are apparent in extracts from stationary phase cells or after high-speed centrifugation of the extract of exponential phase cells (Fig. 4(b) and (e)).

The gel filtration patterns shown in Figure 4 are used to estimate the distribution of molecular sizes in the extracts for molecular masses $\leq 200,000$ 


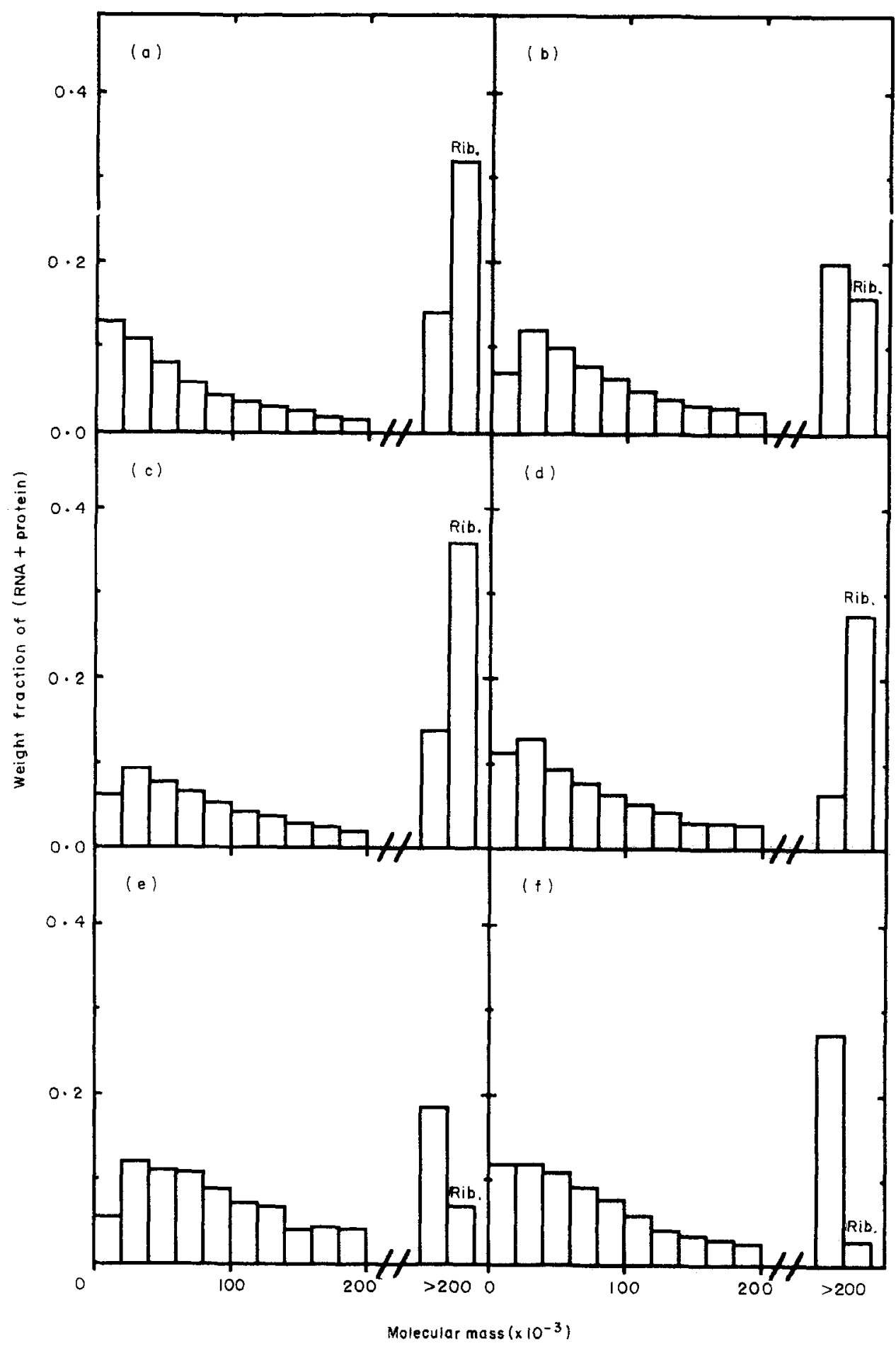

Figure 5. Molecular mass distributions from gel filtration columns of Fig. 4. The pooled fractions containing material of $>200,000 M_{\mathrm{i}}$ are represented as $2 \mathrm{bars}$, one of which is the content of ribosomal particles on the assumption that the RNA in fractions 1 to 18 inclusive of Fig. 4 is ribosomal, and that the ratio of ribosomal protein to RNA is $32 / 68$ in media, of high salt concentration where $\approx 10 \%$ of the proteins are stripped from the particles (van Holde \& Hill, 1973; Spirin, 1986), and a second bar for non-ribosomal materials of $>200,000 M_{\mathrm{i}}$. The relatively small amounts of RNA in fractions 19 and higher of Fig. 4 are treated as equivalent weights of protein of the molecular mass inferred from Fig. 2. (a) to (f) samples as described in the legend to Fig. 4.

(Fig. 5) as described in Materials and Methods. Gel filtration fractions that contained species of $M_{\mathrm{i}}>$ 200,000 are represented in Figure 5 as high molecular mass pools, divided into ribosomal and non-ribosomal subclasses. The actual molecular mass distribution within the high molecular mass pools has only slight effect on the calculations presented here (our unpublished results).

SDS/polyacrylamide gel clectrophoresis was used to compare various cell fractions with each other and the SDS-extracts of whole cells (Fig. 6). The Coomassie blue-stained gel pattern from extracts of 


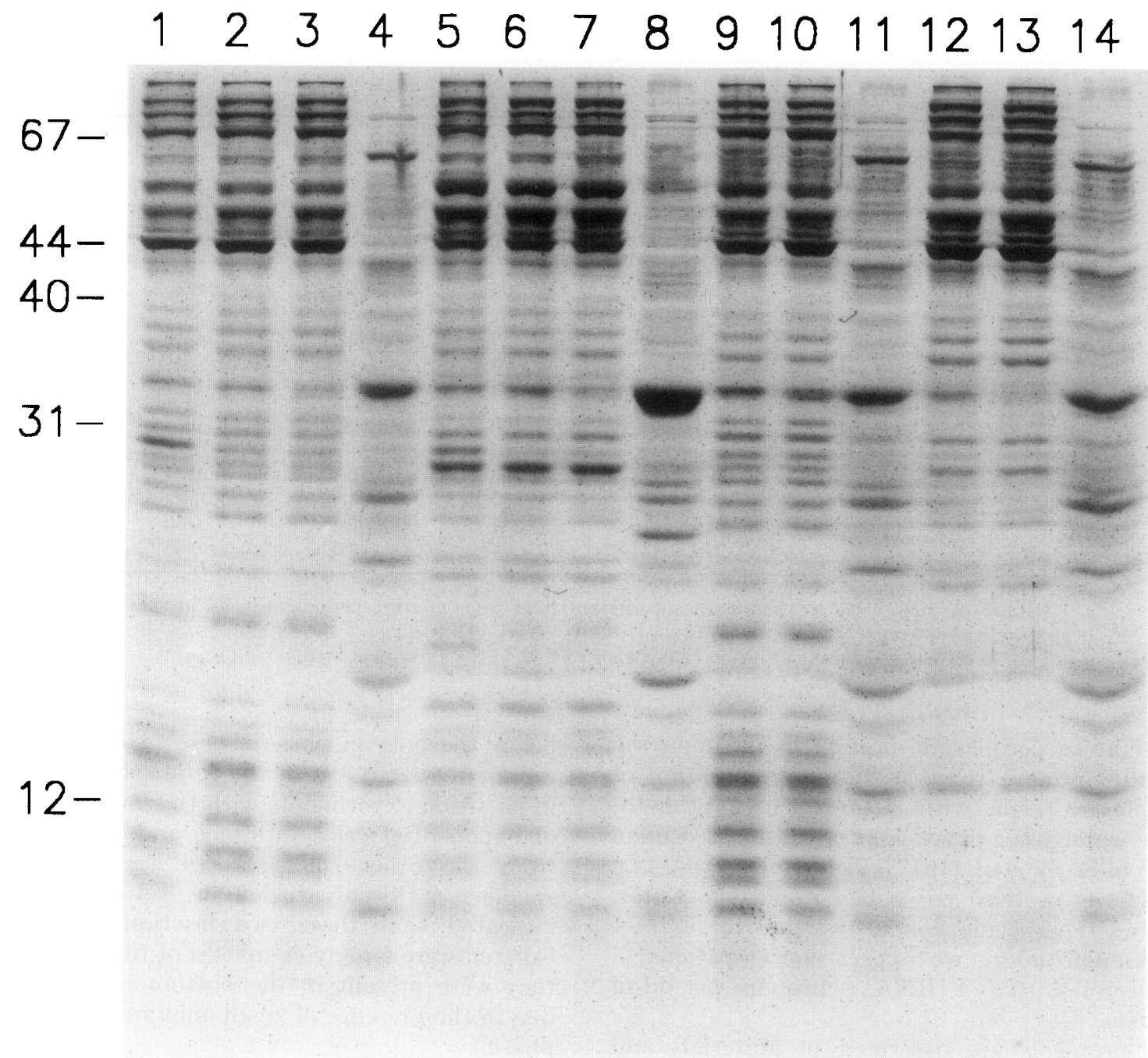

Figure 6. SDS/polyacrylamide gel electrophoresis of extracts of whole cells or spheroplasts from exponential and stationary phase cultures of $E$. coli before and after distribution in the 2-phase assay system. Samples (10 $\mu \mathrm{g})$ of total protein were loaded in each lane. Lane 1 is a sample of washed exponential growth phase $E$. coli and lane 2 is an extract of spheroplasts made from those cells; lanes 3 and 4 are samples from the bottom and top phases, respectively, after distribution of the extract shown in lane 2 in the 2-phase system described in the text. Lanes 5 to 8 are analogous to lanes 1 to 4 but are prepared from stationary growth phase cells. Lane 9 is a sample of the material in an alumina extract of exponential cells that is soluble after low-speed centrifugation, and lanes 10 and 11 are bottom and top phase samples. respectively, after 2-phase distribution of that low-speed extract. Lane 12 is a sample of the material in an alumina extract of exponential cells that is soluble after high-speed centrifugation, and lanes 13 and 14 are bottom and top phase samples, respectively, after 2-phase distribution of that high speed extract. Mobilitics of several purified proteins and their molecular masses $\left(\times 10^{3}\right)$ are indicated on the left.

whole cells or of spheroplasts was very similar to the pattern of the total detergent-extractable proteins from whole cells (Fig. 6, lanes 2 or 9 versus lane 1 ; lasie 6 versus lane 5 ), indicating that both types of extracts reflect the cellular contents. This similarity of the extracts to the total cellular contents is taken to justify certain relatively arbitrary aspects of the extraction protocols, such as the choice of centrifugal force used to separate the extract from "cell debris" or the choice of extraction medium. Soluble protein patterns from extracts of stationary and exponential growth phase cells are generally similar (Fig. 6, lane 1 versus lane 5). Finally, the patterns are consistent with removal of ribosomal components from the high-speed extract (lane 12) and their reduction in stationary phase cells (lanes 5 or 6) as judged by the relative absence of many lower molecular mass proteins.

\section{(c) Concentration of macromolecules in the cytoplasmic compartment of $\mathbf{E}$. coli}

Rough calculations based upon the composition of $E$. coli indicate a very high concentration of macromolecules in the cytoplasm. A value of $\approx 0 \cdot 62$ g of cytoplasmic (RNA + protein) per g dry weight of cells (based on total RNA and total protein values by Neidhardt (1987), allowing $8 \%$ of cell dry weight as cell wall protein based upon pp. 246 and 255 of Salton (1964), and allowing $5 \%$ of cell 
Table 3

Estimation of soluble macromolecule concentrations in the cytoplasmic compartment of E. coli

\begin{tabular}{|c|c|c|c|c|c|}
\hline $\begin{array}{l}\text { Growth phase } \\
\text { of cells }\end{array}$ & $\begin{array}{l}\text { Assay } \\
\text { method }\end{array}$ & $\begin{array}{c}\text { Sucrose } \\
\text { concentrations } \\
(\mathrm{mM} / \mathrm{mm})\end{array}$ & $\begin{array}{c}(\mathrm{RNA}+ \\
\text { protein) in } \\
\text { extract } \\
(\mathrm{mg} / \mathrm{ml})\end{array}$ & $\begin{array}{l}\text { Extract } \\
\text { dilution } \\
\text { (fold) }\end{array}$ & $\begin{array}{l}\text { Estimated } \\
\text { (RNA+ } \\
\text { protein) in } \\
\text { cytoplasm } \\
(\mathrm{g} / \mathrm{ml})\end{array}$ \\
\hline \multirow[t]{5}{*}{ Exponential } & I & $39 \cdot 0 / 25 \cdot 7 \dagger$ & 95 & 3.5 & $0 \cdot 3$ \\
\hline & II & $0 / 0 \ddagger$ & 87 & & \\
\hline & & $21 \cdot 9 / 30 \cdot 5 \ddagger$ & 86 & 36 & $0 \cdot 31$ \\
\hline & II & $0 / 0 \ddagger$ & 90 & & \\
\hline & & $239 / 308+$ & 83 & $4 \cdot 5$ & $0 \cdot 37$ \\
\hline \multirow[t]{6}{*}{ Stationary } & I & $37 \cdot 4 / 25 \cdot 7 \dagger$ & 106 & $4 \cdot 0$ & 04 \\
\hline & II & $0 / 0 \ddagger$ & 80 & & \\
\hline & & $24 \cdot 6 / 30 \cdot 8 \ddagger$ & 69 & $5 \cdot 0$ & 0.34 \\
\hline & II & $0 / 0 \ddagger$ & 95 & & \\
\hline & & $114 / 154 \ddagger$ & 87 & 38 & $0 \cdot 33$ \\
\hline & & $240 / 308 \div$ & 77 & 4.5 & $0 \cdot 35$ \\
\hline
\end{tabular}

$\uparrow$ Ratio of sucrose concentrations in supernatant fluid from mixture containing cells to control mixture without cells.

$\$$ Ratio of sucrose concentrations in cell extract to that in the extraction medium.

dry weight as periplasmic protein based upon the amount of protein released during preparation of spheroplasts) taken with $\approx 1.5$ to $1.8 \mathrm{~g}$ of cytoplasmic water per g dry weight of cells (based upon Table 3 of Stock et al. (1977)) yields $\approx 0.34$ to $0.42 \mathrm{~g}$ of (RNA + protein) per g of cytoplasmic water. Assuming the specific volume we find for extract contents $(0.67 \mathrm{ml} / \mathrm{g})$, we expect concentrations of the order of $\approx 0.3 \mathrm{~g}$ of (RNA + protein) per ml of cytoplasm.

Two protocols are described in Materials and Methods for measuring $C_{\text {cytoplasm }}$, i.e. total (protein + RNA) concentrations in the cytoplasm, in terms of sucrose-impermeable cell volume. The results of these two methods are consistent with each other and with the above estimate: $C_{\text {cytoplasm }}$ values of $\approx 0.34 \mathrm{~g} / \mathrm{ml}$ characterize both exponential and stationary phase cells (Table 3). This value for $C_{\text {cytoplasm }}$ is converted with equation (10) to the values for the excluded volume fraction, $\Phi$, for $v=1.0$ or $1.3 \mathrm{ml} / \mathrm{g}$ in Table 5 .

\section{(d) Two-phase partition of cell extracts}

The partition assay was applied to extracts from exponential or stationary growth phase E. coli. A range of concentrations of each extract was tested, resulting in concentrations in the bottom phase that extended to $>200 \mathrm{mg} / \mathrm{ml}$ of (RNA + protein). The phase components, PEG 8000 and inorganic phosphate, redistributed in response to addition of the extracts similarly to their responses to additions of purified components studied previously (Zimmerman \& Trach, 1990; data not shown). Examples of RNA and protein contents of the phases are indicated in Table 2 . Over $95 \%$ of the (RNA + protein) is present in the bottom, PEG-poor phase. Small amounts of RNA and protein occur as a layer at the interface and as a pellet below the bottom phase. These two fractions each represent $\approx 2$ to $3 \%$ of the total RNA and protein in partition experiments with the low-speed extract of exponential cells; interface and pellet fractions from the other cell extracts were considerably smaller. (SDS/polyacrylamide gel electrophoresis indicated that these two fractions as manually isolated were largely composed of the same proteins that were present in the bottom phase, probably due to the presence of small amounts of the bottom phase.)

The macromolecular composition of the bottom phase should be similar to that of the cell fraction from which it comes if the partition procedure is not introducing artifacts. This similarity is a result of the size-dependence of the partition system, such that macromolecules have distribution coefficients $\ll \mathbf{l}$ and, hence, are largely ronfined to the bottom phase. To evaluate this similarity, samples from the bottom phases were compared with corresponding extracts by their behavior on gel filtration on Sephacryl S-300 (Fig. 4(d) versus (c), (f) versus (e)). by SDS/polyacrylamide gel electrophoresis (Fig. 6 , lanes 3 versus 2.7 versus 6.10 versus 9 , and 13 versus 12), and by agarose/acrylamide gels for ribosomal particles (data not shown). The similarity of the patterns of the bottom phases to those of the extracts or of whole cells generally indicate a lack of significant changes in the extracts that are attributable to the extraction and assay procedures. There is a small loss of ribosomes in the bottom phase relative to the ribosome content of the extract (Fig. 4,(d) versus (c)). The patterns of Figure 6 do not indicate significant degradation by proteases.

The differences in composition in top and bottom phase samples from partition of extracts can be used to check the applicability of the excluded volume basis of the theory described by Zimmerman \& Trach (1990). The two phases should be markedly 
different in composition, again based upon the sizedependence of the distribution coefficient. The high concentration of PEG in the top phase prevented direct measurement of the size distribution of the macromolecules in the top phase under nondenaturing conditions. Such measurements were, however, made after separating the macromolecules of the top phase from the PEG by acid-precipitation. Agreement with the expected size-dependence of the distribution coefficients was good up to at least $\approx M_{\mathrm{r}}=80,000$ (corresponding to $\approx 80 \%$ of the total protein of the cell extract) as shown by comparison of the theoretical, broken lines and the experimental points in Figure $7(\mathrm{e})$ and $(\mathrm{f}) \dagger$.

\section{(e) Excluded volume parameters from partition and gel filtration assays}

The distribution coefficients over the range of extract concentrations tested in the two-phase assay are shown in Figure 8 for the extracts given in Table 2; coefficients are plotted as a function of the concentration of total (RNA + protein) in the bottom phase. Since there is no obvious concentration dependence, we have applied the calibration of Figure 1 to the mean of the five values for each extract shown in Figure 8 to obtain an average molecular mass for that extract. Those molecular masses are then used to calculate values of $R^{*}$ with equation (1) (Table 4). Similar analyses (not shown) based on the distribution properties of the protein component alone indicated that the soluble proteins control the value of $R^{*}$ and, in a real sense, dominate the macromolecular crowding in these extracts.

The values of $R^{*}$ from the two-phase assay data

$\uparrow$ The overall distribution coefficient at a given gel location will be the weight average of the coefficients for the species at that location (Zimmerman \& Trach, 1990 ). Values below the theoretical lines are expected for those polypeptides that are bound in particles or oligomers at the time of distribution between the phases, since such components will have the smaller distribution coefficients of the larger species but will appear on the gel at the position of the polypeptide length. For example, a protein of $M_{\mathrm{r}}=50,000$ composed of two 25,000 polypeptides will appear on the gel at the position of 25,000 species but will have the distribution coefficient $(K)$ of the 50,000 species $(K \approx 0.003)$ rather than that of 25,000 species $(K \approx 0 \cdot 03)$. This effect is particularly marked for ribosomal components, since a particle of ribosomal dimensions has a distribution coefficient $\approx 1000$-fold lower than that of the proteins of which it is composed. While theoretically the aggregation state could be changed by the concentration of extract, no obvious changes in gel patterns have been seen as a function of concentration of extract in the assay for a $>20$-fold difference in total RNA and protein concentration. There are also several polypeptides with $K_{i}$ values much greater than their denatured molecular mass would indicate. Such fluctuations could be the result of an unusually small effective specific volume or from preferential interactions with the PEG 8000.
Table 4

Parameters from two-phase and gel filtration assays of extracts

\begin{tabular}{|c|c|c|c|}
\hline \multirow[b]{2}{*}{ Extract } & \multirow[b]{2}{*}{$\begin{array}{c}v^{\dagger} \\
(\mathrm{ml} / \mathrm{g})\end{array}$} & \multicolumn{2}{|c|}{$R^{*}$} \\
\hline & & $\begin{array}{c}\text { Two-phase } \\
\text { assay } \ddagger \\
\text { (nm) }\end{array}$ & $\begin{array}{c}\text { Gel } \\
\text { filtration } \S \\
(\mathrm{nm})\end{array}$ \\
\hline \multicolumn{4}{|c|}{ A. Exponential phase cells } \\
\hline Low-speed & 1.0 & $2 \cdot 16$ & $2 \cdot 44$ \\
\hline $\begin{array}{l}\text { extracts from } \\
\text { cells }\end{array}$ & $1 \cdot 3$ & $2 \cdot 36$ & $2 \cdot 54$ \\
\hline Low-speed & $1 \cdot 0$ & $2 \cdot 17$ & $2 \cdot 27$ \\
\hline $\begin{array}{l}\text { extracts from } \\
\text { spheroplasts }\end{array}$ & $1 \cdot 3$ & $2 \cdot 37$ & $2 \cdot 37$ \\
\hline High-speed & 1.0 & $2 \cdot 07$ & $2 \cdot 45$ \\
\hline $\begin{array}{l}\text { extract from } \\
\text { cells }\end{array}$ & $1 \cdot 3$ & $2 \cdot 26$ & $2 \cdot 55$ \\
\hline \multicolumn{4}{|c|}{ B. Stationary phase cells } \\
\hline Low-speed & $1 \cdot 0$ & $2 \cdot 08$ & $2 \cdot 31$ \\
\hline $\begin{array}{l}\text { extract from } \\
\text { spheroplasts }\end{array}$ & $1 \cdot 3$ & $2 \cdot 27$ & $2 \cdot 41$ \\
\hline
\end{tabular}

$\dagger$ Assumed effective specific .volume for hard sphere representation.

$¥$ Uncorrected radius of homogeneous solution from 2-phase assays.

$\S$ Values for uncorrected radii of homogeneous solutions calculated as in the text from the molecular mass distributions of Fig. 5.

are compared with theoretical values for $R^{*}$ calculated from the corresponding gel filtration profiles (Table 4). The relatively good agreement between these two sets of values for $R^{*}$ indicate that the extracts partition in the two-phase assay generally as expected from the hard sphere representations of the corresponding gel filtration profiles. This agreement supports the calibrations for Figures 1 and 2 , as well as the use of the gel filtration profiles to correct for the covolume-dependent weighting of $R^{*}$ from the two-phase assay. That correction yields the $R_{\mathrm{e}}$ values of Table 5 , i.e. the values for homogeneous hard sphere solutions that are used as cytoplasm-like background solutions for the calculations in the following section.

The values of $R_{\mathrm{e}}$ are generally comparable to the corresponding $R_{\text {a }}$ values (Table 5), which are based only on the hard sphere representations of the gel filtration profiles.

\section{(f) Calculation of activity coefficients for the cytoplasm of $\mathrm{E}$. coli}

Our goal is to calculate rough activity coefficients for a macromolecule of interest (the "test particle") when present in a distribution of background particles that approximates the macromolecules in the cytoplasm of $E$.coli. Test particles of effective radius $R_{i}$ up to $6 \mathrm{~nm}$ are considered, corresponding to values of $M_{\mathrm{r}} \approx 540,000$ to 420,000 for effective specific volumes $(v)$ of 1.0 to $1.3 \mathrm{ml} / \mathrm{g}$; this choice of $v$-values is based upon results in the Appendix and 


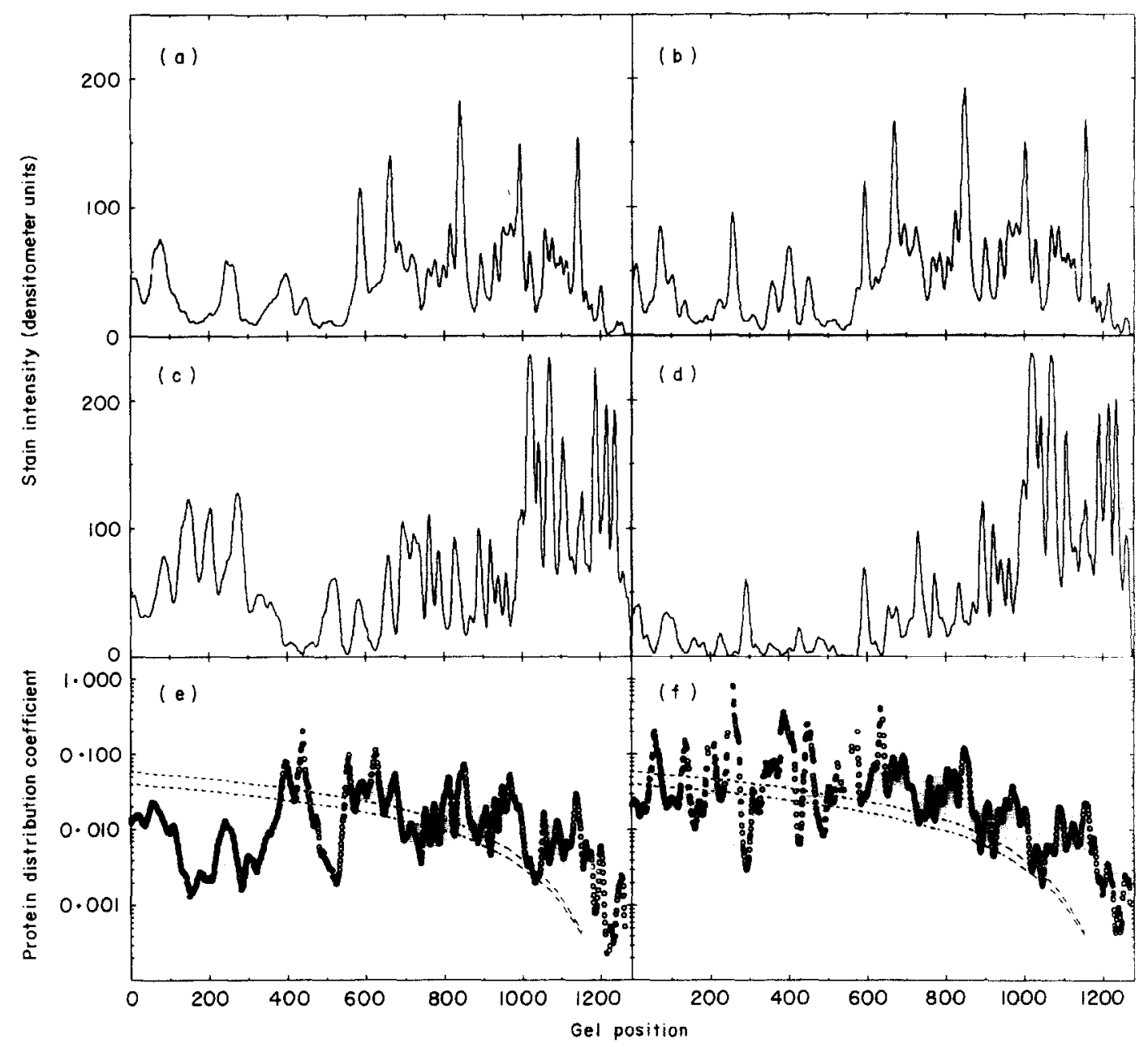

Figure 7. Calculation of $K_{i}$ values from densitometer scans of SDS/polyacrylamide gels of phase samples from low ((a), (c) and (e)) or high-speed ((b), (d) and (f)) extracts. (a) and (c) $10 \mu \mathrm{g}$ of protein of top and bottom phases, respectively. of the low-speed extract of exponential growth phase cells described in Table 1. (b) and (d) $10 \mu \mathrm{g}$ of protein of top and bottom phases, respectively, of the high-speed extract of exponential phase cells described in Table $I$. (e) and ( $f$ ) Distribution coefficients calculated from gel stain intensities at the 1280 equally spaced gel positions sampled by the densitometer. Lower and upper broken lines are theoretical coefficients for $v=1.0$ and $1.3 \mathrm{ml} / \mathrm{g}$, respectively, calculated with eqn (5) of Zimmerman \& Trach (1990), for hard sphere radii at intervals across a gel calculated with eqn (1) using interpolated molecular masses of purified protein standards; gel positions 200,600 and 1000 correspond to $\approx 19,000$, 25,000 and $42,000 M_{\mathrm{r}}$.

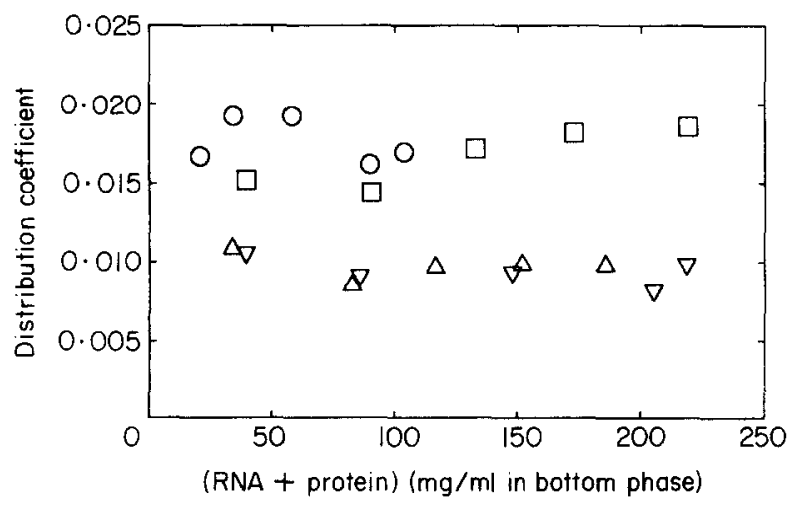

Figure 8. Distribution coefficient of total (RNA + protein) in cell and spheroplast extracts. $(\triangle)$ low-speed extract of exponential phase cells; $(\nabla)$ low-speed extract of exponential phase spheroplasts; $(O)$ high-speed extract of exponential phase cells; $(\square)$ low-speed extract of stationary phase spheroplasts. is considered in detail in the Discussion. Activity coefficients are calculated with a scaled particle equation for the hard sphere representations of extracts from either exponential or stationary growth phase cells. There is approximate agreement between the $\gamma_{i}$ values calculated from the gel filtration profiles of Figure 5 and from partition data for a given value of $v$ (curve 1 versus 2 or curve 3 versus 4 in Fig. 9(a) or (b)). Values for exponential and stationary phase cells were not significantly different (Fig. 9(a) versus (b)).

\section{Discussion}

(a) Assumptions

We assume that the non-nucleoid region of the cytoplasm of $E$. coli can be treated as a simple, concentrated solution of macromolecules. 
Table 5

Parameters of equivalent homogeneous solutions

\begin{tabular}{|c|c|c|c|c|c|}
\hline \multirow[b]{2}{*}{$\begin{array}{l}\text { Growth phase of } \\
\text { cells }\end{array}$} & \multirow[b]{2}{*}{$\begin{array}{c}\text { Estimated excluded } \\
\text { volume fraction } \\
\text { in cytoplasm, } \Phi \dagger \\
(\mathrm{ml} / \mathrm{ml})\end{array}$} & \multicolumn{2}{|c|}{ Two-phase assay } & \multicolumn{2}{|c|}{ Gel filtration } \\
\hline & & $\begin{array}{c}R_{\mathrm{e}} \\
(\mathrm{nm})\end{array}$ & $\begin{array}{l}d_{\mathrm{e}} \dagger \\
\times 10^{-18} \\
\left(\mathrm{~cm}^{-3}\right)\end{array}$ & $\begin{array}{c}R_{\mathrm{a}} \\
(\mathrm{nm})\end{array}$ & $\begin{array}{l}d_{\mathrm{a}} \S \\
\times 10^{-18} \\
\left(\mathrm{~cm}^{-3}\right)\end{array}$ \\
\hline Exponential & $\begin{array}{l}0 \cdot 34 \\
0 \cdot 44\end{array}$ & $\begin{array}{l}3 \cdot 06 \\
3 \cdot 52\end{array}$ & $\begin{array}{l}2 \cdot 8 \\
2 \cdot 4\end{array}$ & $\begin{array}{l}3 \cdot 17 \\
3 \cdot 51\end{array}$ & $\begin{array}{l}2 \cdot 6 \\
2 \cdot 4\end{array}$ \\
\hline Stationary & $\begin{array}{l}0.34 \\
0.44\end{array}$ & $\begin{array}{l}2 \cdot 88 \\
3 \cdot 30\end{array}$ & $\begin{array}{l}3 \cdot 4 \\
2 \cdot 9\end{array}$ & $\begin{array}{l}3 \cdot 10 \\
3 \cdot 43\end{array}$ & $\begin{array}{l}2 \cdot 7 \\
2 \cdot 6\end{array}$ \\
\hline
\end{tabular}

$\dagger$ Using eqn (10) with $C_{\text {cytoplasm }}=0.34 \mathrm{~g} / \mathrm{ml}$ and $v=1.0$ or $1.3 \mathrm{ml} / \mathrm{g}$.

$\$$ Number density of particles of radius $R_{\mathrm{e}}$ for the excluded volume fraction in column 2 .

$\S$ Number density of particles of radius $R_{\mathrm{a}}$ for the excluded volume fraction in column 2 .

Experimental data are used to derive the characteristics of equivalent solutions of hard spheres that are similar to the cytoplasm in their excluded volume effects on added molecules of interest.

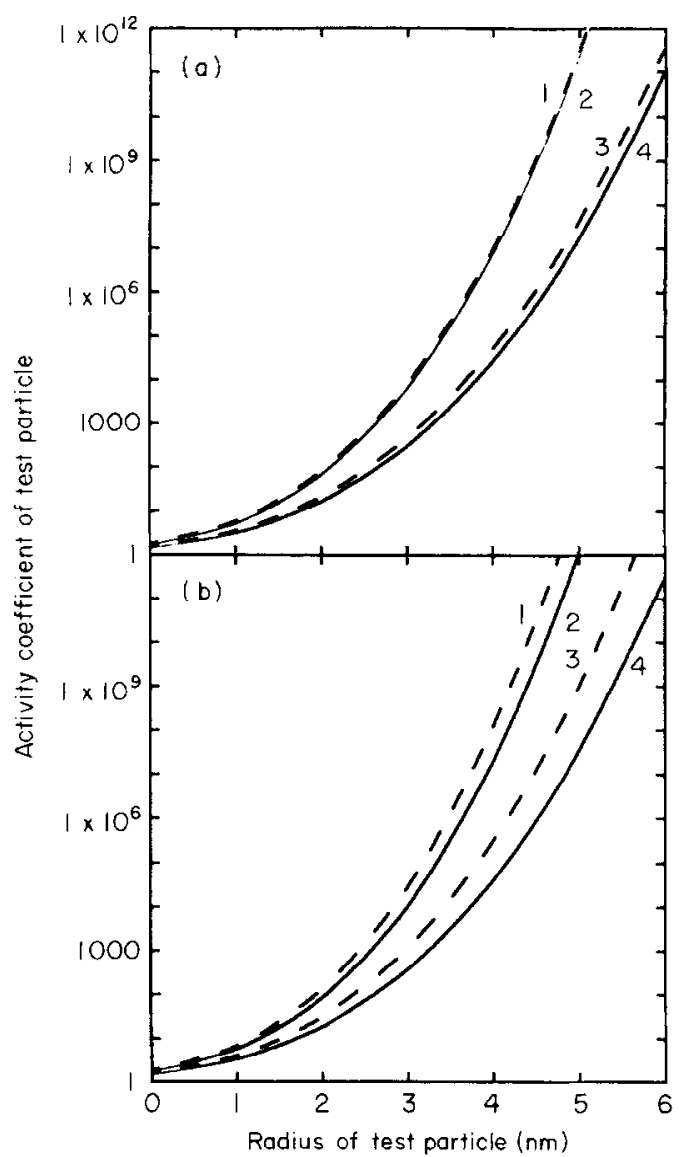

Figure 9. Activity coefficients for test particles of varying sizes under conditions estimated for the cytoplasm of E. coli. (a) and (b) Based on analyses of exponential and stationary phase cell samples, respectively. All calculations assume $C_{\text {cytoplasm }}=0.34 \mathrm{~g} / \mathrm{ml}$. Curves 1 and 2 are for $v=1.3 \mathrm{ml} / \mathrm{g}$ and curves 3 and 4 are for $v=1.0 \mathrm{ml} / \mathrm{g}$. Continuous lines are calculated from the gel filtration profiles of Fig. 5 as in Materials and Methods; values calculated from the corresponding $R_{\mathrm{a}}$ and $d_{\mathrm{a}}$ values in Table 5 were superimposable on the continuous eurves (not shown). Broken lines are calculated for the $R_{\mathrm{e}}$ and $d_{\mathrm{e}}$ values in Table 5
Activity coefficients are calculated for molecules of interest when present in such background solutions.

Hard sphere representations are sought in order to apply scaled particle theory to the calculation of $\gamma$ values. Scaled particle calculations with hemoglobin and other purified macromolecules have been in substantial agreement with experiment over very wide ranges of concentration (Ross \& Minton, 1977a,b; Minton \& Edelhoch, 1982; Minton, 1981, 1983). The use of an effective hard sphere representation for the cytoplasmic contents is supported by the general agreement between the distribution coefficients for the bulk of proteins with values predicted for their hard sphere representations (points versus broken lines in Fig. 7(e) and ( $f$ ).

Since the sizes of the background spheres are estimated from the partition and gel filtration behaviors of the cell extracts, it is important to judge to what extent the extracts resemble the nonnucleoid fraction of the cytoplasm of $E$. coli. The salt concentrations in the partition and gel filtration assays are high $(\approx 0.3$ to 1 M-phosphate buffer plus small amounts of other solutes), but not that much different than values observed in vivo (see discussion by Schultz \& Solomon, 1961; Epstein \& Schultz, 1965). SDS/polyacrylamide gel electrophoresis indicates a protein composition in the phase samples that is very similar to that of the cell. The basic ribosomal structure is stable under distribution conditions, although a fraction of the proteins are stripped from the particles as noted previously. Ribosomes are presumably released from polysomes under extraction and partition conditions; trial calculations (not shown) indicate that such changes do not significantly alter the curves of Figure 9 .

DNA appears to be sequestered in vivo into one or more nucleoids (Ingraham et al., 1983; Woldringh \& Nanninga, 1985) and probably makes little contribution to the excluded volume in the cytoplasmic compartment surrounding the nucleoids. The extracts tested here have been treated with pancreatic DNase I to avoid an undefined partial state of DNA degradation due to endogenous nucleases and to decrease the viscosity of the extracts. Proteins originally bound to the DNA under cellular conditions will be released. It is inter- 
esting that after phage infection, the nucleoid as a separate entity disappears (Snustad \& Conroy, 1974), yielding a cytoplasm that has some similarities to the extracts used in the present assay.

\section{(b) Effective specific volume for crowding interactions}

The value of $v$, the effective specific volume in crowding interactions of a given material as an equivalent hard sphere, has a large effect on the estimates of activity coefficients (see examples in the following section). It is expected (Minton, 1980) that $v$ will have a value between its partial specific volume and its specific volume as a hydrodynamic particle, or roughly between $\approx 0.7$ and $\approx 1.3 \mathrm{ml} / \mathrm{g}$ for a typical protein (Kuntz \& Kauzmann, 1974). In our initial description of the two-phase assay (Zimmerman \& Trach, 1990) we assumed an average effective specific volume in crowding interactions of $1.3 \mathrm{ml} / \mathrm{g}$ dry weight of macromolecule to fix the value of the only adjustable parameter of the assay.

Several considerations indicate that values of $v=1.0$ to $1.3 \mathrm{ml} / \mathrm{g}$ for an average hard sphere effective specific volume in crowding interactions are appropriate in the current study (as well as in our previous study).

(1) The composition of precipitates of a number of proteins from PEG 8000 solutions were used to set limits on the effective specific volume of such materials under crowded conditions (see Appendix). A range of values of $\approx 1.4$ to $1.9 \mathrm{ml} / \mathrm{g}$ dry weight were obtained for the proteins in several media, corresponding to $v \approx 1.0$ to $1.4 \mathrm{ml} / \mathrm{g}$ dry weight when interpreted as equivalent hard spheres.

(2) Crystalline macromolecules are a rich source of information on close-packing. Mathews (1977) tabulated $V_{M}$, the ratio of the volume of the unit cell to the molecular mass of protein in that cell, for 226 protein crystals; values range over $\approx$ threefold and have a small tendency to increase with $M_{\mathrm{r}}$. The most common value of $V_{\mathrm{M}}$ for these crystals was $2 \cdot 2 \AA^{3} /$ dalton, corresponding to $0.98 \mathrm{~cm}^{3} / \mathrm{g}$ for equivalent hard spheres.

(3) Estimates of the fraction of "bound water" in crystals or solutions of protein provide another estimate of $v$, although the definition of bound water is somewhat arbitrary (Kuntz \& Kauzmann, 1974). An average value of $\approx 0.25 \mathrm{~g}$ bound water $/ \mathrm{g}$ protein was suggested by Mathews (1977) for crystalline proteins from results for both crystallographic and other techniques. This fraction of bound water corresponds to $v \approx 1.0 \mathrm{ml} / \mathrm{g}$ protein for equivalent hard spheres (assuming an average partial specific volume of the proteins of $0.73 \mathrm{ml} / \mathrm{g}$ ).

(4) The indicated range for $v$ is probably also consistent with certain in vivo results of Mitchell \& Moyle (1956). They measured cytoplasmic volume (as inorganic phosphate-impermeable volume) of cells of Bacterium coli over a range of $\mathrm{NaCl}$ concentrations. Cytoplasmic volume decreased from a value of $3.09 \mathrm{ml} / \mathrm{g}$ cell dry weight for cells in $0 \cdot 2 \mathrm{~m}-\mathrm{NaCl}$ to approach a limiting value of $1.33 \mathrm{ml} / \mathrm{g}$ cell dry weight at high, plasmolyzing $\mathrm{NaCl}$ concen- trations. If this $2 \cdot 3$-fold increase in concentrations of cytoplasmic constituents is taken to be the limit imposed by close-packing of cytoplasmic constituents, those constituents should then be $2 \cdot 3$-fold more dilute under normal growth conditions and hence occupy $\approx(1 / 2 \cdot 3)=0 \cdot 43 \mathrm{ml} / \mathrm{ml}$ cytoplasm. Applying our experimental value for the macro molecule concentration in cytoplasm of $\approx 0.34 \mathrm{~g}$ (RNA + protein) $/ \mathrm{ml}$ cytoplasm (or $\approx 0.35 \mathrm{~g} / \mathrm{ml}$ including DNA (Neidhardt, 1987)), this occupancy corresponds to a bulk effective specific volume of cytoplasmic macromolecules of $\approx 1.2$ to $1.3 \mathrm{ml} / \mathrm{g}$; to derive an average effective specific volume for a hard sphere representation of the macromolecules. this bulk value must be corrected for an unknown fraction of interstitial volume. Although this bulk value corresponds to $v \approx 0.94 \mathrm{ml} / \mathrm{g} \mathrm{dry}$ weight if the cytoplasm is considered as an equivalent, homogeneous population of spheres, this may not be appropriate model for the actual packing of the cytoplasmic components.

(5) The suggested range in average effective specific volume is not inconsistent with values for individual proteins obtained by fitting a hard sphere model to experimental data $(0.92 \mathrm{ml} / \mathrm{g}$ for hemoglobin (Ross et al., 1978) and $1.5 \mathrm{ml} / \mathrm{g}$ for serum albumin (interpolation of the data in Table 1 of Minton \& Edelhoch (1982) to the $\mathrm{pH}$ value $(\mathrm{pH} 6.9$ to $7 \cdot 0$ ) of the 2 -phase system).

(6) Finally, we note that the activity coefficients estimated by the two experimental techniques agree considerably better with each other for $v=1.0$ or $1.3 \mathrm{ml} / \mathrm{g}$ than for $v=0.7 \mathrm{ml} / \mathrm{g}$ (calculations not shown).

Given the scaled particle equation we uset, the largest source of uncertainty for the calculations of the $\gamma$ values of Figure 9 seems to be in the proper value of $v$. The magnitudes of the effects of the suggested range of $v=1.0$ to $1.3 \mathrm{ml} / \mathrm{g}$ are indicated by the differences beiween curves 1 and 2 versus 3 and 4 of Figure $9(a)$ or (b). Uncertainty in $\gamma$ values from the estimated errors for $(R, d)$ parameters of the various background solutions is probably much less than these differences, given both the agreement between theoretical and observed values of $R^{*}$, and the agreement between parameters for extracts that would be expected to have similar crowding properties (extracts of exponential growth phase cells from spheroplasts versus those from whole cells; high-speed exponential phase extracts versus those from stationary phase extracts). The use of a range for $v$ does not prevent useful esti-

$\dagger$ Berg (1990b) has questioned the omission of solvent as an explicit component in scaled particle calculations; his approach, using an explicit hard sphere representation for water, leads to substantially lower estimates of activity coefficients of test particles. More experimental data against which the predictions can be tested are required before it will be clear whether such a representation provides more accurate estimates than are obtained with the equation of Chatelier \& Minton (1987), used here 
mates of the trends of $\gamma$ values being obtained, as will be illustrated in the following section.

\section{(c) Implications for in vivo function}

In earlier studies, we noted that crowding with synthetic polymers such as polyethylene glycol or dextrans could increase the extent of binding of several DNA polymerases to DNA; the increased binding greatly extended the functional range of the polymerases, counteracting the inhibitory effect from high salt concentrations or from other perturbants. We suggested that macromolecular crowding might have global effects upon intracellular binding reactions; the term metabolic buffering was suggested for the anticipated homeostatic effects of increased binding under highly volume-occupied but perhaps otherwise strongly dissociating conditions (Zimmerman \& Harrison, 1987; Zimmerman \& Trach, 1988a). The motivation for the present study was to provide an experimental basis for estimating the magnitudes of such effects in a biologically interesting sample.

The activity coefficients shown in Figure 9 are large, reinforcing the belief that excluded volume corrections will be important under conditions in vivo. It should be emphasized in the application of the curves of Figure 9 that such corrections are only one aspect of the internal milieu; these corrections may be opposed by non-specific effects such as those due to ion concentrations (see discussion of lac repressor, below) or by specific effects due to interactions with small molecules (substrates and products, allosteric effectors, etc.) or other macromolecules. Further, we re-emphasize that our activity coefficient estimates are dependent upon the assumptions and model we have chosen and can provide "order of magnitude" estimates of activity coefficients at best. Bearing these limitations in mind, the application of values from Figure 9 to solubility and association reactions are illustrated below (see Minton (1981, 1983) for extensive descriptions of effects of crowding upon these reactions). These activity coefficients will also be applied to a striking discrepancy that has been observed between the in vitro and in vivo properties of lar. repressor and of RNA polymerase.

Large values of cytoplasmic activity coefficients suggest that macromolecules, in general, will be much less soluble in cytoplasm than in dilute surroundings. The solubility of a macromolecule is decreased in inverse proportion to its activity coeffi eient (assuming constant activity of the macromolecule in the solid phase: Minton, 1983). The $\gamma_{i}$ values of Figure 9(a) indicate that a relatively insoluble protein of about the size of carbonic anhydrase $\left(M_{\mathrm{i}} \approx 31,000, R_{i} \approx 2.3\right.$ or $2.5 \mathrm{~nm}$ at $v=1.0$ or $1.3 \mathrm{ml} / \mathrm{g}$ ) could be as much as an order of magnitude less soluble in cytoplasm than in a dilute solution containing the same soluble low molecular mass components, whereas a molecule the size of serum albumin $\left(M_{\mathrm{i}} \approx 67,000\right.$, corresponding to $R_{i} \approx 3 \cdot 0$ or
$3.3 \mathrm{~nm}$ ) could be as much as 2 orders of magnitude less soluble.

The position of equilibrium in association reactions is subject to excluded volume effects (Minton, 1981, 1983; Berg, 1990b) if the effective volumes of the reactants and products differ. The effects can be highly model-dependent (Berg, 1990b). We take as an example the equilibrium between a monomer and its dimer, stipulating that the effective volume of the dimer is twice that of the monomer, and assuming a spherical shape for all participants. The apparent equilibrium constant for dimerization, $K_{\text {apparent }}$, is related to the thermodynamic equilibrium constant for dimerization, $K^{0}$, by the activity coefficients of the monomer and dimer:

$$
K_{\text {apparent }}=K^{0} \cdot \frac{\left(\gamma_{\text {monomer }}\right)^{2}}{\gamma_{\text {dimer }}}
$$

For a monomer with molecular mass of $\approx 40,000$, $K_{\text {apparent }}$ would be shifted $\approx$ eightfold to 40 -fold toward dimerization for $v=1.0$ or $1.3 \mathrm{ml} / \mathrm{g}$ at the macromolecular concentrations estimated for $E$. coli cytoplasm. A similar calculation for the equilibrium between a monomer of $\approx 40,000$ molecular mass and its tetramer indicates shifts of $\approx 10^{3}$ to $10^{5}$.

These effects on solubility and association may dramatically affect the formation of aggregates of macromolecules, even those orchestrated by only relatively non-specific, weak molecular interactions. Because $\gamma$ values increase so rapidly with size of the test particle, the tendencies toward insolubility and toward aggregation just discussed may be greatly increased for larger particles such as ribosomal subunits, viruses, etc. in the absence of contravening effects.

The potential of excluded volume effects to rationalize in vivo phenomena is illustrated by application of our results to an interesting discrepancy between in vivo and in vitro behavior shared by two very well-studied proteins, lac repressor and RNA polymerase. Both the binding of lac repressor to DNA (Riggs et al., 1970; Barkley, 1981; Winter et $a l ., 1981)$ and the binding of $E$. coli RNA polymerase to the $\lambda P_{\mathrm{R}}$ promoter (Roe et al., 1984; Roe \& Record, 1985) are strongly inhibited by high salt concentrations in typical uncrowded in vitro solutions. In contrast, Richey et al. (1987) found that both systems are little affected by similarly high intracellular concentrations of salt. They suggested that this difference might be at least partially due to relatively larger numbers of non-specific DNA binding sites in vivo than under typical in vitro conditions. To test the effects of such differences on the expected salt dependencies, they applied the equilibrium model of von Hippel et al. (1974) for competitive binding of repressor to specific versus non-specific DNA sequences. Although the calculations of Richey et al. show that non-specific sequences do, indeed, greatly reduce the salt dependence of repressor-operator binding for both wildtype and the two mutant operators that they char 
acterized, the extents of reduction led them to conclude that "... other features of the in vivo environment are undoubtedly important...". We have used our estimates of activity coefficients in the model of von Hippel et al. (1974) to test the effect of excluded volume in that environment. The interaction of repressor $(\mathrm{R})$ with operator $(\mathbf{O})$ to form the specific complex (RO) is taken to have a thermodynamic association constant $K_{\mathrm{R} O}$ defined by equation (13), where $C$ indicates molar concentration:

$$
K_{\mathrm{RO}}=\frac{C_{\mathrm{RO}}}{C_{\mathrm{R}} C_{\mathrm{O}}} \cdot \frac{\gamma_{\mathrm{RO}}}{\gamma_{\mathrm{R}} \gamma_{\mathrm{O}}} \approx \frac{C_{\mathrm{RO}}}{C_{\mathrm{R}} C_{\mathrm{O}}} \cdot \frac{1}{\gamma_{\mathrm{R}}} .
$$

(An association constant for interaction with nonspecific DNA sites (D), $K_{\mathrm{RD}}$, would be written similarly.) To obtain the values for the activity coefficients of macromolecules from Figure 9 , it is necessary to estimate the sizes of the hard sphere representations of those molecules. It is far from clear how to represent the DNA. Is DNA relatively free in the non-nucleoid cytoplasm or is it relatively immobilized within the nucleoid? It is obviously not well-represented as a sphere. Fortunately, the value of the activity coefficient of the DNA is likely to be similar to that of its complex with repressor, so that changes in the two activity coefficients will tend to cancel each other, as indicated in the approximation in equation (13). In addition, $\gamma_{0}$ and $\gamma_{\mathbf{R O}}$ may be relatively unaffected by excluded volume effects to the extent that the DNA is anchored by supramolecular relationships; if so, these species may suffer only relatively small further entropic changes due to crowded cytoplasmic conditions. The tetrameric lac repressor $\left(M_{\mathrm{r}}=154,000\right.$; Beyreuther, 1978) would be represented by spheres of radius $\approx 3.9$ or $4.3 \mathrm{~nm}$ for $v=1.0$ or $1.3 \mathrm{ml} / \mathrm{g}$, which, based upon Figure $9(\mathrm{a})$, would have values of $\gamma_{\mathrm{R}} \approx 10^{4}$ or $10^{8}$. Such values of $\gamma_{\mathrm{R}}$ yield free energy changes in the binding reaction of $\approx-6$ and $-11 \mathrm{kcal}$ (as compared to values of $\approx-18 \mathrm{kcal}$ for binding under typical dilute solution conditions; $1 \mathrm{cal}=4 \cdot 184 \mathrm{~J}$ (Barkley \& Bourgeois, 1978)).

We have used a modified version of the von Hippel et al. (1974) model to calculate the effect of crowding upon the fraction of unbound lac operator over a range of salt concentrations; details are given in the legend to Figure 10. Adequacy of the calculation is suggested by good correspondence between theory and observed values at low salt levels (curves versus circles, Fig. 10). In the absence of crowding effects, increased salt levels cause a theoretical derepression similar to that calculated by Richey et al. (1987): this salt-induced derepression contrasts with the salt-independence of the experimental data (continuous curves versus squares, Fig. 10). A quite different result is, however, obtained if excluded volume effects are taken into account. Our calculation predicts that excluded volume effects will act in opposition to the salt effect and that corrections in the range anticipated from Figure 9 can reduce the salt dependency to within the experimentally observed range (broken and dotted lines versus squares, Fig, 10)†.

Garner et al. (1990) suggested an explanation for the discrepancy between the in vivo and in vitro salt effects that also stems from possible homeostatic effects of high volume occupancy, but which is based upon an increase in cytoplasmic protein concentration observed in growth media of increased osmolarity. Such increased occupancy should certainly further increase binding; it is not obvious that the increased binding will significantly change levels of gene expression, given the large values that we estimate for the activity coefficient of the repressor under normal growth conditions.

Approximations similar to those made above for the lac repressor can be applied to the $\mathrm{RNA}$ polymerase-promoter interactions. Given the large size of $E$. coli RNA polymerase $\left(M_{\mathrm{r}} \approx 450,000\right.$ : Chamberlin, 1982), crowding alone could make an energetic contribution comparable to or greater than the total binding energies estimated for this equilibrium (Strauss et al., 1980; Roe of al., 1984: Yager \& von Hippel, 1991) at an assumed effective specific volume of either 1.0 or $1.3 \mathrm{ml} / \mathrm{g}$. We conclude that the discrepancy between the in vitro and in vivo results for both lac repressor and for RNA polymerase can be at least partially explained by the anticipated excluded volume effects.

\section{(d) Cell volume and excluded volume effects}

Mitchell \& Moyle (1956) and Stock et al. (1977) have found changes of as much as several-fold in cytoplasmic volume in response to changes in solute concentrations in the culture medium. Hence, it may be possible to cause short-term changes in the level of intracellular crowding in cells like $E$. coli by changing the concentration in the cell suspension medium of low molecular mass solutes such as $\mathrm{NaCl}$ or sucrose, which are excluded from the cytoplasmic

† The basis of this model for excluded volume effects in decreasing the salt sensitivity of repressor binding is an increase in binding constants for both specific: and non-specific binding so that the buffering by non-specific sites is extended nver a larger salt region. as emphasized by a referee.

Calculations in which the $\gamma_{\mathrm{R}}$ values from Fig. 9 are combined with the set of parameters used by Richey of al. (1987) also indicate that crowding effects oppose salt effects (our unpublished results). The parameters of Richey et al. contain adjustments in binding constants that were introduced to fit observed extents of repression at lower salt levels. and in that regard are more arbitrary than the set described in the legend to Fig. 10.

Further calculations with our modified model indicate that as long as the equilibrium between repressor and inducer is not subject to significant excluded volume effects. the extent of induction should not be affected by macromolecular erowding, and also that macromoleculai crowding should not change the fraction of open operator irrespective of the numbers and affinities of the non-specific DNA sites. 


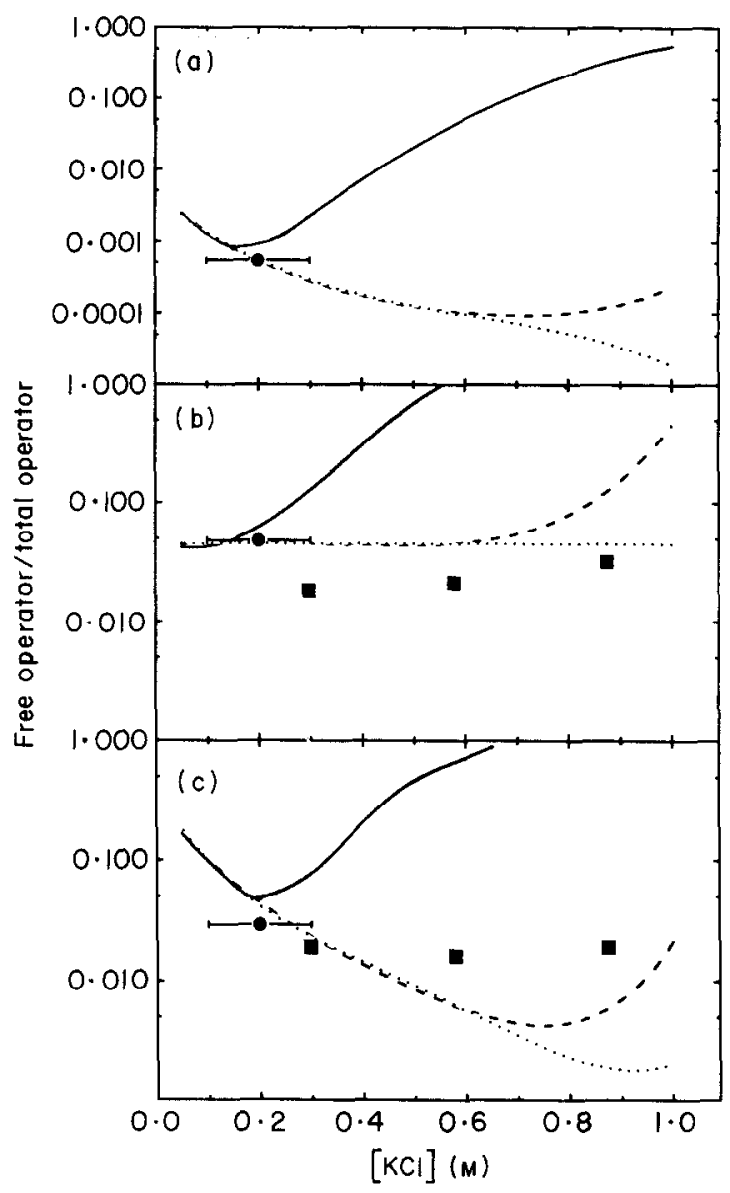

Figure 10. Effects of macromolecular crowding on calculated fractions of free operator in lac repressor- $-\mathrm{DNA}$ equilibria. (a), (b) and (c) Wild-type, $O^{c} 640$ and $O^{c} 666 l a c$ operators, respectively. (O) experimental $P$ values from Jobe et al. (1974) (averaged $P$ values plotted arbitrarily at $0 \cdot 2 \mathrm{M}-\mathrm{KCl}$ with error bar indicating our estimate of range of probable intracellular salt concentrations) and (a) represent values from Richey et al. (1987). Theoretical values for the fraction of open operator are calculated with the model of von Hippel et al. (1974) as modified by eqn (13) for values of $\gamma_{R}=1,10^{4}$, or $10^{8}$ (continuous broken or dotted lines, respectively), Cellular concentrations assumed: total repressor $=1.7 \times 10^{-8} \mathrm{M}$ and total operator sites $=1 \cdot 7^{-9} \mathrm{M}$ based on von Hippel et al. (1974); total non-specific DNA binding sites $=8.3^{4} \mathrm{M}$, corresponding to $5 \%$ of the base-pairs of DNA, based on the paper by Berg (1990a). The relatively small changes in activity coefficient of the salt with concentration (Handbook of Chemistry and Physics, 1964) are ignored. Binding constants are based upon those measured in $3 \mathrm{~mm}-\mathrm{Mg}^{2}+$ for specific interactions of repressor with wild-type operator and for non-specific interaction with $E$. coli DNA by Lin \& Riggs (1975); their eqn (2) was converted to molar units assuming the size of the non-specific binding unit to bc a single base pair of $600 M_{\mathrm{r}}$. Reductions in specific binding constants for $O^{\mathrm{c}} 640$ and $0^{\mathrm{c}} 666$ of 78 -fold and 67 -fold are based on values in Table 2 of Jobe et al. (1974) for wild-type repressor in $0.2 \mathrm{M}-\mathrm{KCl}$. The relative saltdependencies of the operators observed by Mossing \& Record (1985) (but not their absolute values) are maintained, in that the salt-dependence for all non-specific binding constants and for the specific binding constant of $O^{c} 640$ are taken to be the sume as each other, and the salt dependence for specific binding of wild-type operator and of $0^{c} 666$ are taken to be the same as each other. The compartment under most conditions (Schultz \& Solomon, 1961). Such crowding changes may allow internal re-equilibration of certain cellular components with possible applications to industrial or other situations. A potential complication to such experiments is a transient induction of permeability by osmotic shifts (Britten \& McClure, 1962; our unpublished results).

\section{(e) Experimental solutions to replace cytoplasm for in vitro crowding studies?}

In principle, actual solutions of individual macromolecules could be used as artificial, cytoplasm-like backgrounds in experimental studies of crowding effects. The entries for $\Phi=0.34$ or $\Phi=0.44$ in Table 5 correspond to average $M_{\mathrm{r}} \approx 72,000$ or 79,000 , both at $340 \mathrm{mg} / \mathrm{ml}$. A globular protein in this size range and at this concentration might provide a feasible background in which to estimate crowding effects if certain conditions were met. The background macromolecule must neither undergo significant self-aggregation nor specific interactions with the components being tested. It is important to note that at these very high concentrations, even weak specific interactions can become significant, so it is incumbent to test the effect of more than one background material on a test system. Certain of these difficulties may be ameliorated by a suitable choice of solvent and by chemical or genetic engineering of potential background macromolecules.

We also note our unsuccessful earlier attempts to chemically or physically inactivate extracts so that they become innocuous backgrounds. For a variety of crowding-sensitive reactions, only unacceptably harsh treatment of extracts prevented specific interferences such as hydrolysis of substrates or products, precipitation, etc. (our unpublished results).

\section{(f) Further applications of the approach}

The present approach may be applicable to certain other biological materials. It should be wellsuited to Gram-positive bacteria; these cells lack a periplasmic space (Ingraham et al., 1983), considerably simplifying the analysis. The cytoplasm of bacteriophage-infected cells would be of comparative interest, since the host nucleoid structure is degraded (Snustad \& Conroy, 1974).

It should be possible to apply the present

equations used to describe the salt dependencies are:

$$
\begin{gathered}
\log K_{\mathrm{RD}}\left(M^{-1}\right)=-9 \cdot 8 \cdot C^{1 / 2}+7 \cdot 84 \\
\log K_{\mathrm{RO}}\left(M^{-1}\right)=-7 \cdot 3 \cdot C^{1 / 2}+14 \cdot 76 \text { for wild-type } \\
\log K_{\mathrm{RO}}\left(M^{-1}\right)=-9 \cdot 8 \cdot C^{1 / 2}+13 \cdot 99 \text { for } O^{\mathbf{c}} 640 \\
\log K_{\mathrm{RO}}\left(M^{-1}\right)=-7 \cdot 3 \cdot C^{1 / 2}+12 \cdot 93 \text { for } O^{c} 666
\end{gathered}
$$

where the molar concentration of monovalent salt (shown as $\mathrm{KCl}$ in the Figure) is represented by $C$. 
methods to extracts of those eukaryotic cells that have a relatively homogeneous internal structure, such as human or other non-nucleated erythrocytes. In contrast, most eukaryotic cells have complex internal structures, containing large amounts of a variety of filaments and subcellular organelles (Porter, 1985; Osborn \& Weber, 1985). It is not clear whether the "cytosol" of such cells can be profitably used to assess the cytoplasm; Clegg (1984) argued that the simple solution behavior of "cytosol" is an artefact of the extraction process. Extracts of isolated subcellular organelles may, however, be fruitful subjects for the current approach.

It may be noted how easy it is to generatc and manipulate solutions at $>200 \mathrm{mg} / \mathrm{ml}$ of ( $\mathrm{RNA}+$ protein) in the present two-phase system. A second partition would probably yield even higher concentrations. This capability may be useful in other types of studies.

\section{(g) Concluding comment}

We view these experiments and calculations as an initial attempt to define a very complex system. Certain trends seen clear. Given the modeldependence and the approximations of our approach, quantification of in vivo excluded volume cffeets on real systems remains a goal for the future.

\section{APPENDIX}

\section{Effective Hard Sphere Volumes for Macromolecules Based on the Composition of Precipitates from Polyethylene Glycol Solutions}

This Appendix describes a procedure for obtaining the specific volume of proteins or other macromolecules in closely packed precipitates induced with polyethylene glycol (PEG) and isolated by serial centrifugations. These specific volumes are used to estimate corresponding specific volume values for equivalent hard sphere representations of the macromolecules (used in the main text). Although PEG precipitation of proteins has been widely studied (Atha \& Ingham, 1981; Haire et al., 1984; Ingham, 1990; Juckes, 1971; Middaugh et al., 1979; Polson et al., 1964), compositions of the solid phases do not appear to have been described in sufficient detail for the present purposes.

Tared conical capped polypropylene tubes ( $1.5 \mathrm{ml}$, Brinkmann Industrics, Westbury, NY) contained 25 to $50 \mathrm{mg}$ of dry weight of proteins or other macromolecules and varying concentrations of PEG 8000 in solution I (see above) or in solution I containing $0.2 \mathrm{M}$-potassium phosphate buffer $(\mathrm{pH} \mathrm{7.0)}$ (total vol. $=1.2 \mathrm{ml}$ ). After 20 minutes at $20^{\circ} \mathrm{C}$ with repeated mixings, tubes were subjected to a series of centrifugations for 20 -minute periods at $20^{\circ} \mathrm{C}$ at increasing centrifugal forces (Sorvall model RC-5 centrifuge, angle-head rotor (model SS-34) with adapters yielding $R_{\max } \approx 7 \mathrm{~cm}$ ): after an initial centrifugation at $9000 \mathrm{revs} / \mathrm{min}$, the bulk of the fluid was removed for analyses by pipetting and the remaining supernatant fluid was removed by aspiration through small-diameter tubing without disturbing the pellet $\dagger$; the tube and contents were

$\uparrow$ Proteins can form a liquid second phase in the presence of PEG under certain circumstances (Edmond \& Ogston, 1968; Juckes, 1971; see Ingham, 1978). Several of the albumin and aldolase samples formed liquid liquid 2-phase systems in which the bottom phase largely or entirely solidified during the course of the centrifugal treatments. weighed to yield the weight of the wet pellet, $w_{\text {wet pellet }}$ Tubes were then centrifuged for 20 minutes at $13,000 \mathrm{revs} / \mathrm{min}$, at $16,000 \mathrm{revs} / \mathrm{min}$, at $18,500 \mathrm{revs} / \mathrm{min}$, and finally at $20,000 \mathrm{revs} / \mathrm{min}$, aspirating and weighing after each centrifugation. Wet pellets were finally resuspended in $0.8 \mathrm{ml}$ of cold $5 \%$ trichloroacetic acid for ten minutes at $0^{\circ} \mathrm{C}$ and centrifuged for ten minutes at $20,000 \mathrm{revs} / \mathrm{min}$ at $5^{\circ} \mathrm{C}$ to precipitate the protein and other macromolecules and to extract the PEG and salts. Portions of this extract were assayed as described previously to determine the total weight in the pellets of PEG $\left(w_{\mathrm{PEG}}\right)$ and of inorganic phosphate $\left(w_{\text {phosphate }}\right)$ (Zimmerman \& Trach, 1990). The acidinsoluble pellets were lyophilized for a few hours and then dried to constant weight in vacuo at $104^{\circ} \mathrm{C}$ to obtain the dry weight of the protein or other macromolecules, $w_{\text {dry pellet }}$. Control experiments indicated that acid-precipitation of the macromolecules was quantitative and that the trichloroacetic acid did not contribute to the final weight of the dried pellets. Control tubes were used to correct for a characteristic decreasc $(\approx 2.5 \mathrm{mg})$ in tare weight of the tubes that occurs during vacuum drying.

The limiting weight of the wet pellet when no more fluid can be removed by centrifugation, $w_{\text {wet pellet, was estimated for the five centrifugations }}^{0}$ before acid precipitation from the $y$-intercept of plots of the value for $w_{\text {wet pellet }}$ after a centrifugation versus the weight loss in that centrifugation (Fig. Al). The total weight of water, $w_{\text {water }}$ was obtained as:

$$
\left(w_{\text {wct pellet }}^{0}-w_{\text {dry pcllct }}-w_{\text {PEG }}-w_{\text {phosphate }}\right) ;
$$

this value differed by $<3 \%$ from water weight measured directly for a number of samples by vacuum drying of wet pellets that were not acid-precipitated. 


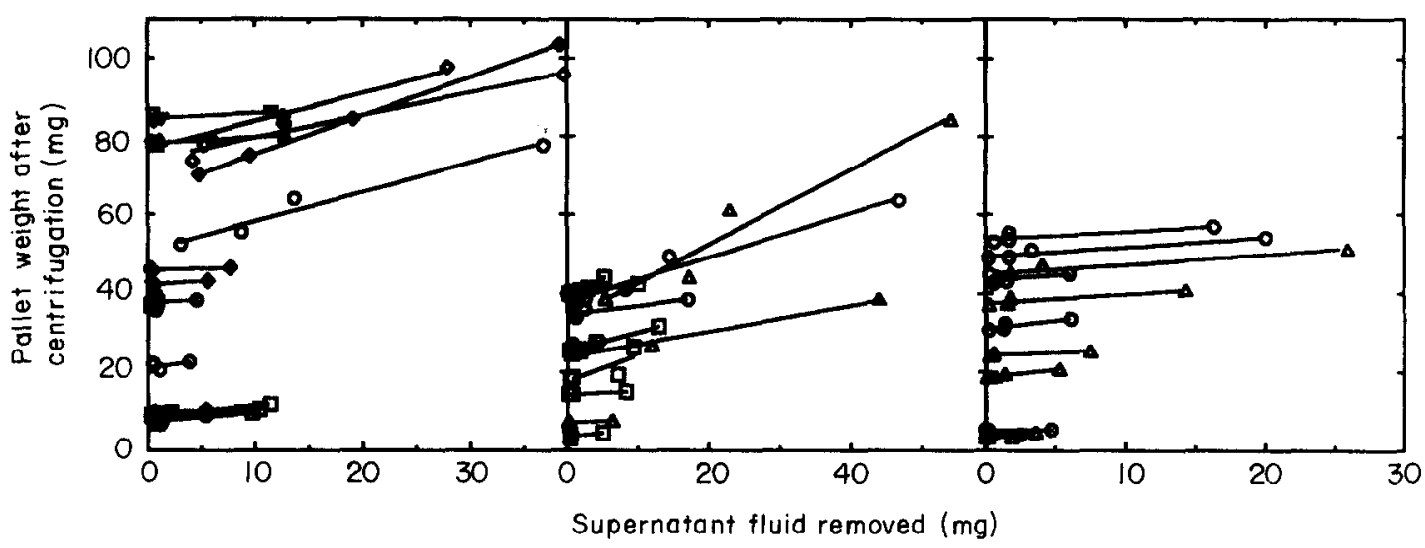

(a)

(b)

(c)

Figure A1. Pellet weight as a function of loss of supernatant fluid in successive centrifugations. Lines are first-order regression fits to the data points. (c) For clarity, values for extract samples in solution I are not shown; their behavior was similar to those shown for samples in $0.2 \mathrm{~m}$-phosphate/solution I.

For calculation of the volume of the wet pellet, we assume specific volumes $(\mathrm{ml} / \mathrm{g})$ for water of $1 \cdot 00$, for proteins of $0 \cdot 73$ (Kuntz \& Kauzmann, 1974), for PEG 8000 of 0.83 (Molyneaux, 1983) and for phosphate of 0.30 (obtained from direct measurement in preparation of buffer stock used in the 2-phase system). The specific volume for macromolecules in the pellet is obtained by equation (A1):

$$
\begin{aligned}
& \text { specific volume }= \\
& \frac{w_{\text {water }}+0 \cdot 73 w_{\text {dry pellet }}+0 \cdot 83 w_{\mathrm{PEG}}+0 \cdot 30 w_{\text {phosphate }}}{w_{\text {dry pellet }}+w_{\text {PEG }}} .
\end{aligned}
$$

Average compositions of the pellets are summarized in Table A1. For the samples precipitated from $0.2 \mathrm{~m}$-phosphate/solution I, PEG was largely absent from the pellets ( $<3 \%$ of the pellet weight, corresponding to $\approx 1 / 4$ of the initial PEG concentration); in contrast, inorganic phosphate was highly concentrated in the pellets of these samples, fortuitously reaching levels comparable to those used in the distribution and gel filtration assays of the main text.

The values of $w_{\text {wet pellet }}$ were little affected by changes in centrifugal force or by changes in PEG concentration over significant ranges of either variable. This invariance indicates that a limit in packing density was being approached. Since phase separation of proteins by $\mathrm{PEG}$ appears to result from excluded volume effects (Edmond \& Ogston, 1968; Juckes, 1971; Middaugh et al., 1979; Atha \& Ingham, 1981; Knoll \& Hermans, 1983; Ingham, 1990), we took the limiting specific volume values

Table A1

\begin{tabular}{|c|c|c|c|c|c|c|c|}
\hline \multirow[b]{2}{*}{ Addition $†$} & \multirow[b]{2}{*}{ Medium +} & \multicolumn{4}{|c|}{$\begin{array}{c}\text { Composition of } 20,000 \text { revs/min } \\
\text { pellet }(\%, w / w) \S\end{array}$} & \multicolumn{2}{|c|}{ Pellet/Bulk\| } \\
\hline & & Water & $\begin{array}{l}\text { Acid- } \\
\text { insoluble }\end{array}$ & PEG & Phosphate & PEG & Phosphate \\
\hline Proteins & Phosphate/ & $\begin{array}{l}43 \cdot 8 \\
(5 \cdot 2)\end{array}$ & $\begin{array}{l}47 \cdot 2 \\
(4 \cdot 7)\end{array}$ & $\begin{array}{c}2 \cdot 5 \\
(1 \cdot 9)\end{array}$ & $\begin{array}{c}6 \cdot 4 \\
(3 \cdot 1)\end{array}$ & $\begin{array}{c}0.26 \\
(0 \cdot 20)\end{array}$ & $\begin{array}{c}5.8 \\
(3.0)\end{array}$ \\
\hline Cell extracts & Phosphate/ & $55 \cdot 9$ & $33 \cdot 5$ & $2 \cdot 3$ & 8.17 & 0.23 & $5 \cdot 6$ \\
\hline$(7)$ & soln I & $(3 \cdot 9)$ & $(3 \cdot 6)$ & $(0 \cdot 9)$ & $(1 \cdot 8)$ & $(0 \cdot 04)$ & $(1 \cdot 2)$ \\
\hline $\begin{array}{l}\text { Proteins } \\
\text { (14) }\end{array}$ & Soln I & $\begin{array}{c}54 \cdot 1 \\
(10 \cdot 3)\end{array}$ & $\begin{array}{l}38 \cdot 3 \\
(11 \cdot 4)\end{array}$ & $\begin{array}{c}8 \cdot 8 \\
(5 \cdot 8)\end{array}$ & nd & $\begin{array}{c}0 \cdot 69 \\
(0 \cdot 37)\end{array}$ & nd \\
\hline $\begin{array}{l}\text { Cell extracts } \\
\text { (10) }\end{array}$ & Soln I & $\begin{array}{l}55 \cdot 9 \\
(2 \cdot 9)\end{array}$ & $\begin{array}{l}34 \cdot 6 \\
(6 \cdot 0)\end{array}$ & $\begin{array}{c}9 \cdot 5 \\
(6 \cdot 9)\end{array}$ & nd & $\begin{array}{c}0 \cdot 67 \\
(0 \cdot 32)\end{array}$ & nd \\
\hline $\begin{array}{l}\text { Ovalbumin } \\
\text { (5) }\end{array}$ & $\mathrm{pH} 5$ & $\begin{array}{l}44 \cdot 0 \\
(5 \cdot 7)\end{array}$ & $\begin{array}{l}54 \cdot 8 \\
(4 \cdot 9)\end{array}$ & $\begin{array}{c}1.8 \\
(0.8)\end{array}$ & nd & $\begin{array}{c}0 \cdot 22 \\
(0 \cdot 05)\end{array}$ & nd \\
\hline
\end{tabular}

Composition of precipitates from PEG 8000 solutions

† All samples shown in Fig. A2 are included here except where the extent of precipitation by $P E G$ was $<1 / 3$ of total acid-insoluble material. The number of tubes analyzed is shown in parentheses.

\$ See Materials and Methods for the composition of solution I; where phosphate is indicated, $0 \cdot 2 \mathrm{M}$-potassium phosphate buffer $(\mathrm{pH} 7 \cdot 0)$ is present as well as the components of solution I. For the pH 5 series, final reaction mixtures contained the components of solution I but were at $\mathrm{pH} 5 \cdot 0( \pm 0 \cdot 1)$.

$\S$ Numbers in parentheses are standard deviations. nd, not determined.

|| Apparent concentration of indicated material in water of the pellet divided by its concentration in the original reaction mixture. Numbers in parentheses are standard deviations. 


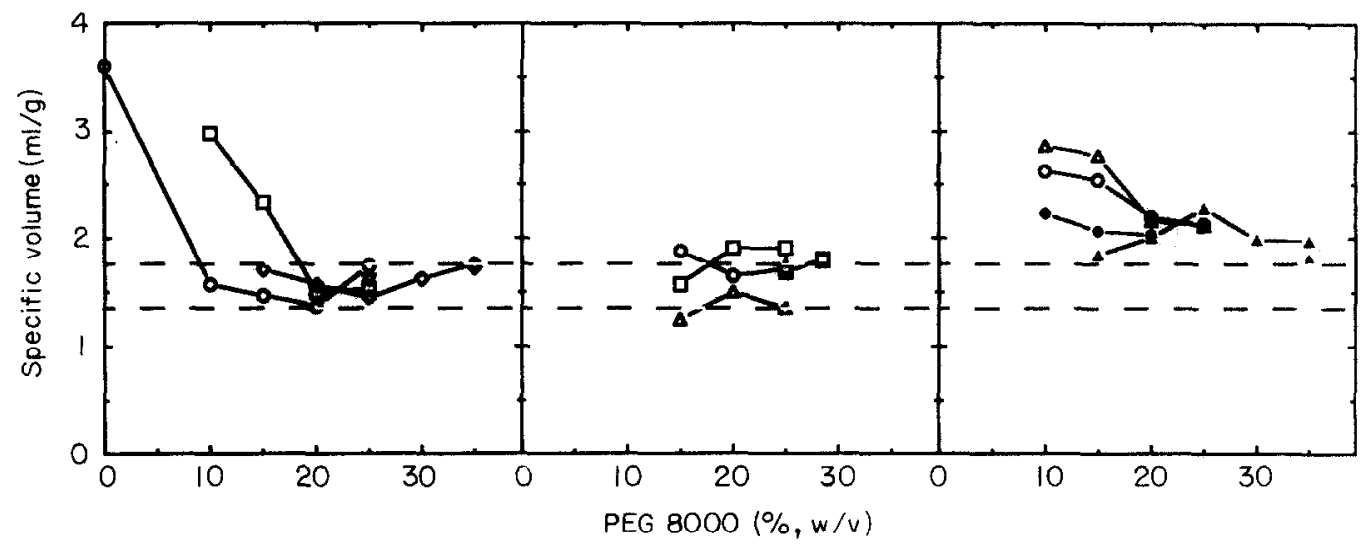

(a)

(b)

(c)

Figure A2. Specific volumes for macromolecules in PEG 8000-induced precipitates. Specific volumes were caleulated as in eqn (A1). Lower and upper broken lines are specific volume values corresponding to hard sphere specific volumes (i.e. $v$ values of the main text) of 1.0 and $1.3 \mathrm{ml} / \mathrm{g}$, respectively. (a) Ovalbumin: $(\square, \nabla)$ phosphate/solution $\mathrm{I} ;(O)$ solution $\mathrm{I} ;(\mathrm{O}, \triangle) \mathrm{pH}$ 5: triangles and inverted triangles indicate addition of double the amounts of protein present for the circles or squares, respectively. (b) (O) Aldolase; ( $\square$ ) plasma albumin; ( $\triangle$ ) lysozyme: phosphate/solution $I$. (c) $E$. coli extracts: $(O, \triangle)$ phosphatc/solution $\mathrm{I} ;(\boldsymbol{O}, \Delta)$ solution I: Circles, extracts of exponential phase cells; triangles, extracts of stationary phase cells.

obtained as those of macromolecules closely packed by volume exclusion. These values can be used to calculate the specific volume of an equivalent hard sphere representation by applying a volumeoccupancy of $74 \%$ for close-packed spheres (Scott, $1960)$

Specific volumes calculated with equation (A1) are shown in Figure $\mathrm{A} 2(\mathrm{a})$ and (b) for several proteins in several media, and in (c) for exponential and stationary phase extracts of $E$. coli. The experimental values for the proteins seem to be consistent with the range of 1.0 to $1.3 \mathrm{ml} / \mathrm{g}$ for equivalent hard sphere specific volumes (shown by lower and upper broken lines in Fig. A2) that is used in the main text for calculation of certain excluded volume effects. The specific volumes of the extracts are somcwhat higher than those of the homogeneous materials. While this increase may reflect actual differences in specific volumes of materials, it seems more likely to be a result of less dense packing because of molecular size heterogeneity (Dickinson \& Parker, 1985). The estimates of hard sphere specific volumes obtained here are compared with those from other sources in the Discussion in the main text.

The criticisms of Gary Felsenfeld, Mark Garner, Allen Minton and Philip Ross on the first draft of the manuscript were very much appreciated, as are discussions with Eduardo Padlan. The anonymous comments of the referees were most helpful. We thank Otto Berg for the opportunity to read his manuscript before publication.

\section{References}

Ashwell, G. (1957). Colorimetric analysis of sugars. Methods Enzymol. 3, 73-107.

Atha, D. H. \& Ingham, K. C. (1981). Mechanism of precipitation of proteins by polyethylene glycols. $J$. Biol. Chem. 256, 12108-12117.
Barkley, M. D. (1981). Salt dependence of the kinetics of the lac repressor-operator interaction: role of nonoperator deoxyribonucleic acid in the association reaction. Biochemistry, 20, 3833 3841

Barkley, M. D. \& Bourgeois, S. (1978). Repressor recognition of operator and effectors. In The Operon (Miller. J. H. \& Reznikoff. W. S. eds). pp. 177220 . Cold Spring Harbor Laboratory Press, Cold Spring Harbor. NY.

Berg. O. G. (1990a). The role of non-specific interactions for gene-regulatory proteins in their search for specific target sites. In The Biology of Nonspecific DNA-Protein Interactions (Revzin. A.. ed.), pp. 71-85, CRC Press, Boca Raton. FI.

Berg, O. G. (1990b). The influence of macromolecular crowding on thermodynamic activity: solubility and dimerization constants for spherical and dumbell. shaped molecules in a hard-sphere mixture. Biopolymers, 30, 1027-1037.

Beyreuther, K. (1978). Chemical structure and functional organization of lac repressor from Escherichia coli. In The Operon (Miller. .J. H. \& Reznikoff. W. S.. eds). pp. 123-154, Cold Spring Harbor Laboratory Press. Cold Spring Harbor, $\mathrm{NY}$

Blakesley, R. W. \& Boezi, J. A. (1977). A new staining technique for proteins in polyacrylamide gels using Coomassie brilliant blue G250. Anal. Biochem. 82. 580582

Britten. R. J. \& Meclure, F. T. (1962). The amino acid pool in Escherichia coli. Bacteriol. Rev. 26, 292 335.

Chamberlin, M. J. (1982). Bacterial DNA-dependent RNA polymerases. In The Enzymes (Bover. P. D.. ed.). 3rd edit, vol 1: part B, pP 61 86 , Academic Press. New York.

Chatelier, R. C. \& Minton, A. P. (1987). Sedimentation equilibrium in macromolecular solutions of arbitrary concentration. I. Self-associating proteins. Biopolymers, 26, 507-524.

Chrambach, A. (1985). Physical characterization by molecular radius and weight. The Practice of Quantitative Gel Electrophoresis. p. 128. VCH Publishers, Deerfield Beach, Florida.

(legg, J. S. (1984). Properties and metabolism of the 
aqueous cytoplasm and its boundaries. Amer. $J$. Physiol. 246, R133-R151.

Dickinson, E. \& Parker, R. (1985). Polydispersity and the fluid-crystalline phase transition. J. Phys. Letters, 46. L229-L232.

Edmond, E. \& Ogston, A. G. (1968). An approach to the study of phase separation in ternary aqueous systems. Biochem. J. 109, 569-576.

Epstein, W. \& Schultz, S. G. (1965). Cation transport in Escherichia coli. V. Regulation of cation content. $J$. Gen. Physiol. 49, 221-234.

Forchhammer, J. \& Lindahl, L. (1971). Growth rate of polypeptide chains as a function of the cell growth rate in a mutant of Escherichia coli 15. J. Mol. Biol. $55,563-568$.

Fulton, A. B. (1982). How crowded is the cytoplasm? Cell, $30,345-347$.

Garner, M. M., Cayley, D. S. \& Record, M. T., Jr (1990). Calculation of macromolecular crowding effects on protein-DNA interactions in vivo. Biophys. J. 57, $62 a$

Gornall, A. G., Bardawill, C. J. \& David, M. M. (1949). Determination of serum proteins by means of the biuret reaction. J. Biol. Chem. 177, 751-766.

Handbook of Chemistry and Physics (1964). Activity coefficients of acids, bases and salts (Weast, R.C., ed.), 45th edit., p. D-80, Chemical Rubber Co., Cleveland, $\mathrm{OH}$.

Haire, R. N., Tisel, W. A., White, J. G. \& Rosenberg, A. (1984). On the precipitation of proteins by polymers: the hemoglobin-polyethylene glycol system. Biopolymers, 23, 2761-2779.

Ingham, K. C. (1978). Precipitation of proteins with polyethylene glycol: characterization of albumin. Arch. Biochem. Biophys. 186, 106-113.

Ingham, K. C. (1990). Precipitation of proteins with polyethylene glycol. Methods Enzymol. 182, 301-306.

Ingraham, J. L.. Maaløe, O. \& Neidhardt, F. C. (1983). Growth of the Bacterial Cell, Sinauer Associates, Sunderland. MA.

Jobe, A., Sadler, J. R. \& Bourgeois, S. (1974). lac repressor-operator interaction. IX. The binding of lac repressor to operators containing $\mathrm{O}^{\mathfrak{c}}$ mutations. J. Mol. Bivl. 85, 231-248.

Juckes, I. R. M. (1971). Fractionation of proteins and viruses with polyethylene glycol. Biochim. Biophys. Acta, 229, 535-546.

Kennell, D. \& Riezman, H. (1977). Transcription and translation initiation frequencies of the Escherichia coli lac operon. J. Mol. Biol. 114, 1-21.

Knoll, D. \& Hermans, J. (1983). Polymer-protein inter actions: comparison of experiment and excluded volume theory. $J$. Biol. Chem. 258, 5710-5715.

Kuntz, T. D., Jr \& Kalumann, W. (1974). Hydration of proteins and polypeptides. Advan. Protein Chem. 28, $239-345$.

Laemmli, C. K. (1970). Cleavage of structural proteins during the assembly of the head of bacteriophage $\mathrm{T} 4$. Nature (London), 227, 680-685.

Lin, S.-Y. \& Riggs, A. D. (1975). The general affinity of lac repressor for E. coli DNA: implications for gene regulation in procaryotes and eucaryotes. Cell, 4, $107-111$.

Lombard, A. \& Chargaff, E. (1957). Aspects of the invariability of a bacterial ribonucleic acid. Biochim. Biophys. Acta, 25, 549-554

Lowry, O. H. Rosehrough, N. I., Farr, A. I. \& Randall, R. J. (1951). Protein measurement with the Folin phenol reagent. J. Biol. Chem. 193, 265-275.
Maniatis, T., Fritsch, E. F. \& Sambrook, J. (1982). Media and antibiotics. Molecular Cloning: $A$ Laboratory Manual, p. 68, Cold Spring Harbor Laboratory Press, Cold Spring Harbor, NY.

Mathews, B. W. (1977). X-ray structures of proteins. In The Proteins (Neurath, H. \& Hill, R. L., eds), vol. 3 , 3rd edit. pp. 403-590, Academic Press, New York.

Mendelsohn. J. \& Tissières, A. (1959). Variations in the amount of ribonucleoprotein particles in Escherichia coli. Biochim. Biophys. Acta, 35, 248-250.

Middaugh, C. R., Tisel, W. A., Haire, R. N. \& Rosenberg, A. (1979). Determination of the apparent thermodynamic activities of saturated protein solutions. J. Biol. Chem. 254, 367-370.

Minton, A. P. (1980). Thermodynamic non-ideality and the dependence of partition coefficient upon solute concentration in exclusion chromatography. Application to self-associating and non-selfassociating solutes. Application to hemoglobin. Biophys. Chem. 12, 271-277.

Minton, A. P. (1981). Excluded volume as a determinant of macromolecular structure and reactivity. Biopolymers, 20, 2093-2120.

Minton, A. P. (1983). The effect of volume occupancy upon the thermodynamic activity of proteins: some biochemical consequences. Mol. Cell. Biochem. 55 $119-140$.

Minton. A. P. (1990). Holobiochemistry: an integrated approach to the understanding of biochemical mechanism that emerges from the study of proteins and protein associations in volume-occupied solutions. In Structural and Organizational Aspects of Metabolic Regulation (Srere, P. A., Jones, M. E. \& Mathews, C. K., eds) pp. 291-306, Wiley, New York.

Minton, A. P. \& Edelhoch, H. (1982). Light scattering of bovine serum albumin solutions: extension of the hard particle model to allow for electrostatic repulsion. Biopolymers, 21, 451-458.

Mitchell, P. \& Moyle. J. (1956). Osmotic function and structure in bacteria. In Bacterial Anatomy, pp. 150 180, 6th Symposium Soc. General Microbiology University Press, London.

Molyneux, P. (1983). Non-ionic polymers: polyoxides, polyethers, and poly(ethylene imine). In Water-Soluble Synthetic Polymers: Properties and Behavior, vol. 1, pp. 39, CRC Press, Boca Raton, FL.

Monsigny, M., Petit, C. \& Roche, A.-C. (1988). Colorimetric determination of neutral sugars by a resorcinol sulfuric acid micromethod. A nal. Biochem. $175,525-530$

Mossing, M. C. \& Record, M. T., Jr (1985). Thermodynamic origins of specificity in the lac repressor-operator interaction. Adaptability in the recognition of mutant operator sites. J. Mol. Biol 186, $295-305$.

Neidhardt, F. C. (1987). Chemical composition of Escherichia coli. In Escherichia coli and Salmonella typhimurium: Cellular and Molecular Biology (Neidhardt, F. C. ed.), pp. 3-6. ASM, Washington. DC.

Oliver, D. B. (1987). Periplasm and protein secretion. In Escherichia coli and Salmonella typhimurium Cellular and Molecular Biology (Neidhardt, F. C. ed.), pp. 56-69, ASM, Washington, DC

Osborn, M. \& Weber, K. (1985). The cytoskeleton. In The Organization of Cell Metabolism (Welch, G. R. \& Clegg, J. S.. eds). pp. 27-35, Plenum Press, New York.

Polson, A. Potgieter. G. M., Largier. J. F.. Mears, 
G. E. F. \& Joubert, F. J. (1964). The fractionation of protein mixtures by linear polymers of high molecular weight. Biochim. Biophys. Acta, 82 463-475.

Porter, K. R. (1985). Structural organization of the cytomatrix. In The Organization of Cell Metabolism (Welch, G. R. \& Clegg, J. S., eds), pp. 9-25, Plenum Press, New York.

Reiss, H. (1965). Scaled particle methods in the statistical thermodynamics of fluids. Advan. Chem. Phys. 9 $1-84$.

Richey, B., Cayley, D. S., Mossing, M. C., Kolka, C. Anderson, C. F., Farrar, T. C. \& Record, M. T., Jr (1987). Variability of the intracellular ionic environment in Escherichia coli. J. Biol. Chem. 262. 7157-7164.

Riggs, A. D., Bourgeois, S. \& Cohn, M. (1970). The lac repressor-operator interaction. III. Kinetic studies. J. Mol. Biol. 53, 401-417.

Roberts, R. B., Cowie, D. B., Abelson, P. H., Bolton, E. T. \& Britten, R. J. (1955). Permeability of the cel wall. Studies of Biosynthesis in Escherichia coli, pp. 58-94, Carnegie Institution of Washington. Washington, DC.

Roe, J.-H., Burgess, R. R. \& Record, M. T., Jr (1984) Kinetics and mechanism of the interaction of Escherichia coli RNA polymerase with the $\lambda P_{\mathrm{R}}$ promoter. J. Mol. Biol. 176, 495-521.

Roe, J.-H. \& Record, M. T., Jr (1985). Regulation of the kinetics of the interaction of Escherichia coli RNA polymerase with the $\lambda P_{\mathrm{R}}$ promoter by salt concentra tion. Biochemistry, 24, 4721-4726.

Ross, P. D. \& Minton, A. P. (1977a). Analysis of non-ideal behavior in concentrated hemoglobin solutions. J. Mol. Biol. 112, 437-452.

Ross, P. D. \& Minton, A. P. (1977b). Hard quasispherical model for the viscosity of hemoglobin solutions. Biochem. Biophys. Res. Commun. 76, 971-976.

Ross, P. D., Briehl, R. W. \& Minton, A. P. (1978). Temperature dependence of non-ideality in concentrated solutions of hemoglobin. Biopolymers, 17. $2285-2288$.

Salton, M. R. J. (1964). The Bacterial Cell Wall, Elsevier, Amsterdam.

Schultz, S. G. \& Solomon, A. K. (1961). Cation transport in Escherichia coli. I. Intracellular $\mathrm{Na}$ and $\mathrm{K}$ concentrations and net cation movement. J. Gen. Physiol. $45,355-369$

Scott, G. D. (1960). Packing of spheres. Nature (London), 188, 908-909.

Sigma Technical Bulletin (1982). SDS molecular weight markers in a discontinuous buffer. no. MWS-877L (10-82), Sigma, St. Louis.

Sirlin, J. L. (1972). Molecular species of RNA. In Biology of RNA, pp. 51-83, Academic Press, New York.

Snustad, D. P. \& Conroy, L. M. (1974). Mutants of bacteriophage $\mathbf{T 4}$ deficient in the ability to induce nuclear disruption. I. Isolation and genetic characterization. J. Mol. Biol. 89,663-673.

Spirin, A. S. (1986). Structural transformations of ribosomes (in vitro). In Ribosome Structure and Protein Synthesis, pp. 162-183, Benjamin/Cummings, Menlo Park, CA.

Stock, J. B., Rauch, B. \& Roseman, S. (1977) Periplasmic space in Salmonella typhimurium and Escherichia coli. J. Biol. Chem. 252, 7850-7861.
Strauss, H. S., Burgess, R. R. \& Record, M. T., Jr (1980) Binding of Escherichia coli ribonucleic acid polymerase holoenzyme to a bacteriophage $\mathrm{T} 7$ promotercontaining fragment: evaluation of promoter binding constants as a function of solution conditions Biochemistry, 19, 3504-3515.

Tissières, A., Watson, J. D., Schlessinger, D. \& Hollingworth, B. R. (1959). Ribonucleoprotein particles from Escherichia coli. J. Mol. Biol. 1, 221-233.

Traub, P., Mizushima, S., Lowry, C. V. \& Nomura, M (1971). Reconstruction of ribosomes from subribosomal components. Methods Enzymol. 20 (part C), 391-407.

van Holde, K. E. \& Hill, W. E. (1973). General physical properties of ribosomes. In Ribosomes (Nomura, Y., Tissières, A. \& Lengyel, P., eds), pp. 53-91, Cold Spring Harbor Laboratory Press, Cold Spring Harbor, NY.

von Hippel, P. H., Revzin, A., Gross, C. A. \& Wang, A. C (1974). Non-specific DNA binding of genome regulating proteins as a biological control mechanism: 1 The lac operon: equilibrium aspects. Proc. Nat. Acad. Sci., U.S.A. 71, 4808-4812.

Weibull, C. (1956). Bacterial protoplasts; their formation and characteristics. In Bacterial Anatomy, pp. 111-126, 6th Symposium of Soc. Gen. Microb. University Press, London.

Winkler, H. H. \& Wilson, T. H. (1966). The role of energy coupling in the transport of $\beta$-galactosides by Escherichia coli. J. Biol. Chem. 241, 2200-2211.

Winter, R. B., Berg, O. G. \& von Hippel, P. H. (1981) Diffusion-driven mechanisms of protein translocation on nucleic acids. 3. The Escherichia coli lac repressor-operator interaction: kinetic measurements and conclusions. Biochemistry, 20, 696l-6977.

Witholt, B., Boekhout, M., Brock, M., Kingma, J.. van Heerikhuizen, H. \& de Leij, L. $(1976 a)$. An efficient and reproducible procedure for the formation of spheroplasts from variously grown Escherichia coli. Anal. Biochem. 74, 160-170.

Witholt, B., van Heerikhuizen, H. \& de Leij, L. (1976b) How does lysozyme penetrate through the bacterial outer membrane? Biochim. Biophys. Acta, 443. $534-544$.

Woldringh, (. L. \& Nanninga, N. (1985). Structure of nucleoid and cytoplasm in the intact cell. In Molecular Cytology of Escherichia coli (Nanninga, N.. ed.), pp. 161-197. Academic Press, New York

Yager, T. D. \& von Hippel, P. H. (1991). A thermodynamic analysis of RNA transcript elongation and termination in Escherichia coli. Biochemistry, 30. $1097-1118$

Zimmerman. S. B. \& Harrison, B. (1987). Macromolecular crowding increases binding of DNA polymerase to DNA: an adaptive effect. Proc. Nat. Acad. Sci. U.S.A. 84, 1871-1875.

Zimmerman, S. B. \& Trach, S. O. (1988a). Macromolecular crowding extends the range of conditions under which DNA polymerase is functional. Biochim. Biophys. Acta, 949, 297-304.

Zimmerman, S. B. \& Trach, S. O. (1988b). Effects of macromolecular crowding on the association of $E$. coli ribosomal particles. Nucl. Acids Res. 16, 6309-6326.

Zimmerman, S. B. \& Trach, S. O. (1990). Excluded volume effects on the partition of macromolecules between two liquid phases. Biopolymers, 30, 703-718. 